\title{
New thylacocephalans from the Cretaceous Lagerstätten of Lebanon
}

\author{
Sylvain Charbonnier ${ }^{1, *}$, Giorgio Teruzzi ${ }^{2}$, Denis Audo ${ }^{3}$, Maxime Lasseron ${ }^{1}$, Carolin Haug ${ }^{4}$ and \\ Joachim T. Haug ${ }^{4}$ \\ ${ }^{1}$ Muséum national d'Histoire naturelle, Paris ; centre de recherche sur la paléobiodiversité et les paléoenvironnements (CR2P, \\ UMR 7207), Sorbonne universités, MNHN, UPMC, CNRS, 57 rue Cuvier 75005 Paris, France \\ 2 Museo di Storia Naturale di Milano, Sezione di Paleontologia degli Invertebrati, Corso Venezia 55, 20121 Milano, Italy \\ ${ }^{3}$ Université de Rennes 1, géosciences Rennes UMR 6118, campus de Beaulieu, 35042 Rennes, France \\ ${ }^{4}$ LMU Munich, Department of Biology II and GeoBio-Center, Großhaderner Str. 2, 82152 Martinsried-Planegg, Germany
}

\begin{abstract}
Thylacocephalans (Euarthropoda, Thylacocephala) are characterized by their "bivalved" carapace and three anterior prehensile appendages. It is still not clear how they used to live, or what their evolutionary history is. This study focuses on new thylacocephalans from the Late Cretaceous KonservatLagerstätten of Lebanon, which yielded the youngest representatives of the group. Three new genera and species are described in the Cenomanian sublithographic limestones of Hakel and Hadjoula, and two new genera and one new species are described in the Santonian chalky limestones of Sahel Alma. Among the specimens from Hakel and Hadjoula, Paradollocaris vannieri, Thylacocaris schrami and Globulacaris garassinoi are the first reports of thylacocephalans in the Cenomanian of Lebanon. Paradollocaris and Thylacocaris are assigned to Dollocarididae based upon their large optic notches limited by rostral and antero-ventral processes, their hypertrophied eyes, and their posterior notches with dorsal and ventral spines. Moreover, Thylacocaris presents a very peculiar character: an optic notch with two strong optic spines protecting the eye. Globulocaris is assigned to Protozoeidae based upon its small carapace with a distinct dorsal notch anterior to a strong postero-dorsal spine. Among the specimens from Sahel Alma, Keelicaris deborae is a new form of thylacocephalans in the Santonian of Lebanon. It presents a very unusual keel-shaped carapace with terraces and punctuations, and is assigned to Microcarididae. The new genus Hamaticaris, presenting a very peculiar hooked rostrum, is also erected for Protozoea damesi Roger, 1946 (Roger J. 1946. Invertébrés des couches à poissons du Crétacé supérieur du Liban. Mémoires de la Société géologique de France (Nouvelle série) 51: 5-92). These two species add to the well-known thylacocephalans from Sahel Alma: Pseuderichtus cretaceus Dames, 1886 (Dames W. 1886. Ueber einige Crustaceen aus den Kreideablagerungen des Libanon. Zeitschrift der Deutschen Geologischen Gesellschaft 38: 551-575), Protozoea hilgendorfi Dames, 1886 and Thylacocephalus cymolopos Lange et al., 2001 (Lange S, Hof CHJ, Schram FR, Steeman FA. 2001. New genus and species from the Cretaceous of Lebanon links the Thylacocephala to the Crustacea. Palaeontology 44 (5): 905-912). The occurrence of such diverse fauna of thylacocephalans markedly increases the diversity of the group during the Late Cretaceous. The diversity and abundance of the Sahel Alma thylacocephalans pose also the problem of causes of their disappearance from the fossil record after the Santonian.
\end{abstract}

Keywords: Euarthropoda / Thylacocephala / new genera / Cenomanian / Hakel / Hadjoula / Sahel Alma / Lebanon

Résumé - Nouveaux thylacocéphales des Lagerstätten du Crétacé du Liban. Les thylacocéphales (Euarthropoda, Thylacocephala) sont des euarthropodes caractérisés par leur carapace «bivalve» et leurs trois appendices préhensiles antérieurs. Leur mode de vie et leur histoire évolutive sont encore loin d'être bien connus. La présente étude documente de nouveaux thylacocéphales issus des Konservat-Lagerstätten du Crétacé supérieur du Liban qui ont livré les représentants les plus récents du groupe. Trois nouveaux genres et espèces sont décrits dans les calcaires sublithographiques cénomaniens de Hakel et de Hadjoula, et deux nouveaux genres et une nouvelle espèce sont décrits dans les calcaires crayeux santoniens de Sahel

\footnotetext{
${ }^{*}$ Corresponding author: scharbonnier@mnhn.fr
} 
Alma. Parmi les spécimens de Hakel et de Hadjoula, Paradollocaris vannieri, Thylacocaris schrami et Globulacaris garassinoi sont les premières mentions de thylacocéphales dans le Cénomanien du Liban. Paradollocaris et Thylacocaris sont assignés aux Dollocarididae sur la base de leurs larges encoches optiques limitées par des processus rostraux et antéro-ventraux, de leurs yeux hypertrophiés, et de leurs encoches postérieures avec des épines dorsales et ventrales. De plus, Thylacocaris présente un caractère très singulier : une encoche optique avec deux grosses épines optiques protégeant l'œil. Globulocaris est assigné aux Protozoeidae sur la base de sa petite carapace avec une très nette encoche dorsale à l'avant de l'épine postéro-dorsale. Parmi les spécimens de Sahel Alma, Keelicaris deborae est une nouvelle forme de thylacocéphales dans le Santonien du Liban. Possédant une très inhabituelle carapace en forme de quille de navire avec des côtes et des ponctuations, il est assigné aux Microcarididae. Le nouveau genre Hamaticaris, présentant un rostre crochu très particulier, est aussi érigé pour Protozoea damesi Roger, 1946 (Roger J. 1946. Invertébrés des couches à poissons du Crétacé supérieur du Liban. Mémoires de la Société géologique de France (Nouvelle série) 51:5-92). Ces deux espèces s'ajoutent aux thylacocéphales bien connus de Sahel Alma: Pseuderichtus cretaceus Dames, 1886 (Dames W. 1886. Ueber einige Crustaceen aus den Kreideablagerungen des Libanon. Zeitschrift der Deutschen Geologischen Gesellschaft 38: 551-575), Protozoea hilgendorfi Dames, 1886 et Thylacocephalus cymolopos Lange et al., 2001 (Lange S, Hof CHJ., Schram FR, Steeman FA. 2001. New genus and species from the Cretaceous of Lebanon links the Thylacocephala to the Crustacea. Palaeontology 44 (5): 905-912). La présence d'une faune aussi variée de thylacocéphales augmente la diversité du groupe durant le Crétacé supérieur. La diversité et l'abondance des thylacocéphales de Sahel Alma posent aussi le problème des causes de leur disparition du registre fossile après le Santonien.

Mots clés : Euarthropoda / Thylacocephala / nouveaux genres / Cénomanien / Hakel / Hadjoula / Sahel Alma / Liban

\section{Introduction}

Thylacocephalans are among the most intriguing euarthropods of the Palaeozoic and Mesozoic eras. They have a long stratigraphic record ranging from the Silurian (Haug et al., 2014) and possibly earlier (Vannier et al., 2006: Cambrian) to the Late Cretaceous (Dames, 1886; Schram et al., 1999), when they probably became extinct. They have a high palaeobiogeographic distribution and are known from all continents except Antarctica and South America (Hegna et al., 2014). They are notably known from Scotland, Spain, France, Germany, Italy, Austria, Slovenia, Lebanon, Madagascar, China, Australia, United States, Mexico, and more recently from Japan (Ehiro et al., 2015).

Their anatomy, mode of life and phylogenetical affinities have remained largely unresolved (Lange et al., 2001; Rolfe, 1985; Schram, 2014; Schram et al., 1999; Vannier et al., 2006; Vannier et al., 2016). Thylacocephans are characterized by a metamerized body protected by a sclerotized "bivalved" carapace (in the wide sense), a pair of compound eyes, sometimes very large, and three pairs of prominent prehensile appendages with spiny tips converging towards the mouth. In the case of some Jurassic taxa such as Dollocaris Van Straelen, 1923, these appendages distantly recall the raptorial appendages of extant mantis shrimps (stomatopod crustaceans) and suggest predatory and hunting habits (Charbonnier, 2009; Charbonnier et al., 2010; Vannier et al., 2016).

Historically, thylacocephalans have been tentatively assigned to a great variety of crustacean groups (e.g., stomatopods: Fraas, 1878; Hilgendorf, 1885; Roger, 1946, decapods: Secrétan, 1985, cirripedes: Arduini et al., 1980). More recently, Haug et al. (2014) have proposed a sister-group relationship with Remipedia based on morphological similarities between Thylacares from the Waukesha fauna (Silurian, Wisconsin) and extant remipedes. These resemblances concern the multisegmented and undifferentiated nature of the trunk, and the number and detailed morphology of the sub-chelate raptorial appendages. According to Vannier et al. (2016), this tentative placement of Thylacocephala close to remipedes is questionable given major differences between the two groups in terms of body organisation and exoskeletal structure. As the time of writing, the exact affinities of Thylacocephala still remain an open question.

This paper reports new occurrences of thylacocephalans in the Cretaceous Konservat-Lagerstätten from Lebanon. It increases the palaeobiodiversity of last representatives of the group during the Cenomanian (Hakel, Hadjoula) and the Santonian (Sahel Alma) just before their assumed extinction. In addition, the new species provide new insights on the morphology of Thylacocephala that may prove useful to understand the affinities and ecology of these euarthropods.

\section{Geological setting}

The three classical Konservat-Lagerstätten of Lebanon, Hakel, Hadjoula and Sahel Alma (Fig. 1), contain a remarkably preserved marine fauna dominated by fishes (Actinopterygii, Chondrichthyes: Forey et al., 2003; Gayet et al., 2003) and euarthropods (Crustacea, Merostomata, Thylacocephala), associated with numerous soft-bodied organisms (Coleoidea, Polychaeta). Hakel and Hadjoula are both late Cenomanian in age (Hemleben, 1977; Wippich and Lehmann, 2004). Sahel Alma is late Santonian in age (Ejel and Dubertret, 1966; Roger, 1946), and is currently inaccessible, being in private property covered by olive trees and possibly entirely exhausted.

Hadjoula and Hakel. - These two Lagerstätten are located in northwest Lebanon, $c a 10 \mathrm{~km}$ east of Byblos (Jbail). They correspond to sublithographic limestones probably deposited in small shallow basins comprising intra-shelf depressions (see review in Audo and Charbonnier, 2012). The sublithographic limestones are intensely excavated for fossils, which are sold to tourists and collectors, but also for scientific studies. By far, 


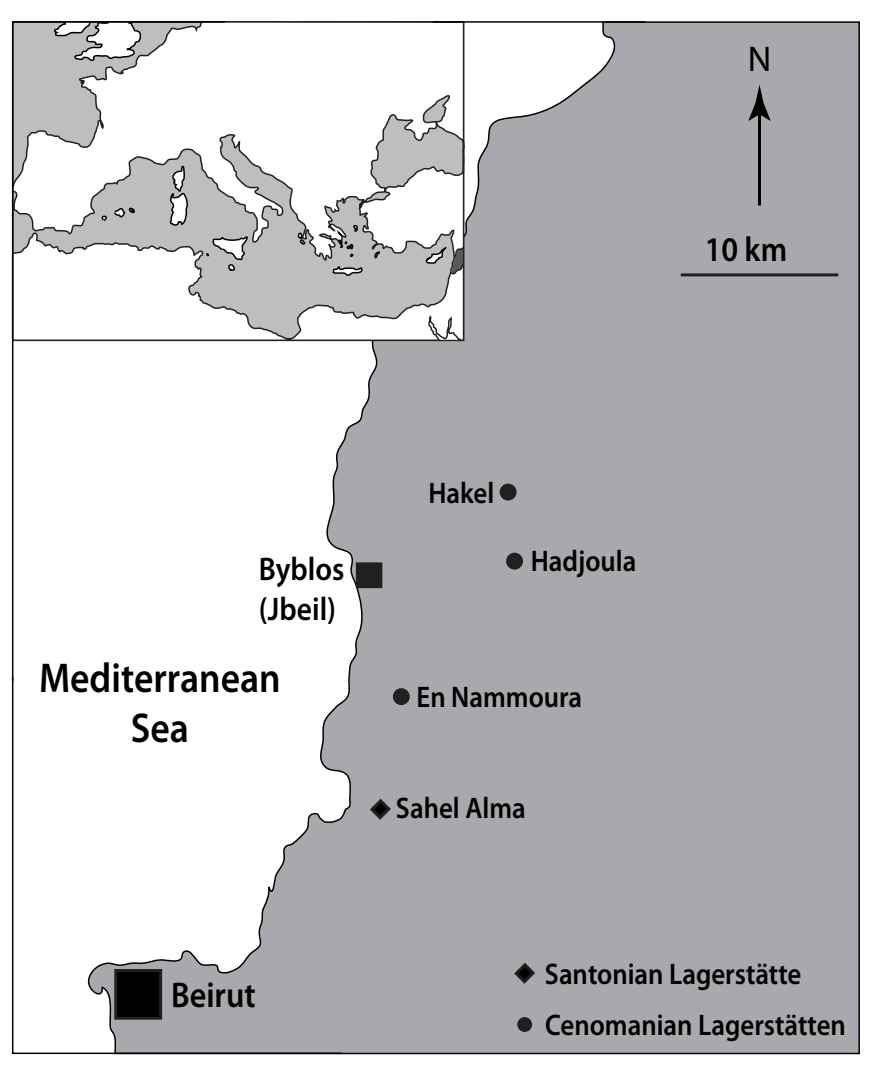

Fig. 1. Map of Lebanon showing the main fossiliferous localities yielding exceptionally preserved Cenomanian faunas (Hadjoula, Hakel, En Nammoura Lagerstätten) and Santonian faunas (Sahel Alma Lagerstätte).

the most abundant animals found in the Hadjoula and Hakel biota are the fishes (in the wide sense) with a prolific and varied assemblage of chondrichthyans and osteichthyans, both found in large numbers on bedding planes (Gayet et al., 2003). Euarthropods are also common, represented by decapod crustaceans (Charbonnier et al., 2017; Garassino, 1994, 2001 Glaessner, 1945; Haug et al., 2016; Roger, 1946), stomatopods (Ahyong et al., 2007), isopods (unpublished) and thylacocephalans (this work). The euarthropods are most frequently preserved as compressions on the surface of sublithographic limestone.

Sahel Alma.-The Sahel Alma Lagerstätte is located in northwest Lebanon, $\mathrm{ca} 20 \mathrm{~km}$ northeast of Beirut. The "fishbeds" of Sahel Alma correspond to chalky laminated limestones formed in much deeper environments than those recognized in Hadjoula or Hakel. They were deposited during an acceleration of the subsidence of the Arabian craton. This acceleration of subsidence is probably a consequence of the onset of the collisional trend, which was responsible for the closing of the Tethys (Ferry et al., 2007). During a field trip to Lebanon in 2011, survey in the vicinity of Sahel Alma did not result in the discovery of any traces of the outcrop. Apparently, the outcrop is in a private property, where some years ago an olive grove was planted. The outcrop is therefore not available for new excavations anymore.

The Sahel Alma fauna comprises numerous chondrichthyans and osteichthyans (Gayet et al., 2003), cephalo- pods (Jattiot et al., 2015; Roger, 1946) and rare annelids (Bracchi and Alessandrello, 2005). Euarthropods are the most common fossils, represented by decapod crustaceans (Audo and Charbonnier, 2013; Brocchi, 1875; Charbonnier et al., 2017; Garassino, 1994, 2001; Roger, 1946), cirripedes (Gale, 2016), isopods (Feldmann, 2009; Feldmann and Charbonnier, 2011) and dominated by thylacocephalans (Dames, 1886; Lange et al., 2001; Schram et al., 1999).

\section{Material and methods}

The examined thylacocephalans come from Hakel (1 specimen), Hadjoula (23 specimens), and Sahel Alma (92 specimens). Most of the Cenomanian (Hakel, Hadjoula) specimens were collected during a field trip in 2011 organized by the Paris Museum and conducted by one of the authors (SC). Santonian (Sahel Alma) specimens were collected during the expedition of the professor Camille Arambourg in Syria and Iran (19381939). They are all housed in the palaeontological collections of the Muséum national d'Histoire naturelle, Paris, France (acronym: MNHN). Other specimens are housed in the Museo di Storia Naturale in Milano, Italy (acronym: MSNM) and were collected by Alessandro Garassino or donated by private collectors.

Thylacocephalans from Hakel and Hadjoula are all preserved flattened on sublithographic limestones. The cuticle is relatively well preserved but is generally microfractured due to the compaction. An important recrystallization of the fossil can also occur, however infrequently. Their aspect varies from whitish on cream-coloured sediment to red-brownish, this latter case possibly corresponding to weathering of the fossil. Thylacocephalans (and also crustaceans) are distinctly autofluorescent under UV light (appear yellow) and green light (appear light orange).

The specimens were therefore documented under macrofluorescence settings and also under cross-polarised light; both methods enhance the contrast between fossil and surrounding matrix (for details see Haug et al., 2009, 2011, 2012). Some of the best-preserved specimens were partially prepared manually with a fine needle to allow a more detailed description.

The specimens from Sahel Alma are preserved within a soft, chalky limestone. UVautofluorescence of the specimens (and also crustaceans) is generally faint or absent and can only be observed for some specimens, under the right conditions and with an adapted colour processing of pictures. All the specimens were studied using a binocular and a camera lucida. Imaging of specimens were variably realized in natural light or UV fluorescence (pictures by L. Cazes, P. Loubry and GT), cross-polarized light (pictures by DA), or green fluorescence (pictures by JTH and $\mathrm{CH}$ ).

Natural light pictures give a good idea of the aspect of the specimen to the naked eye. They are obtained with a diffuse white light source and without polarizing filter. Crosspolarized light pictures are obtained by illuminating specimens with polarized light and cancelling most of the reflected light with a polarizer on the camera lens. This set-up allows to reduce drastically glare and enhance contrast of the specimen (Bengtson, 2000).

UV fluorescence is obtained by illuminating the fossil by a "dark-light" (blue to UV light). Under this kind of light, 

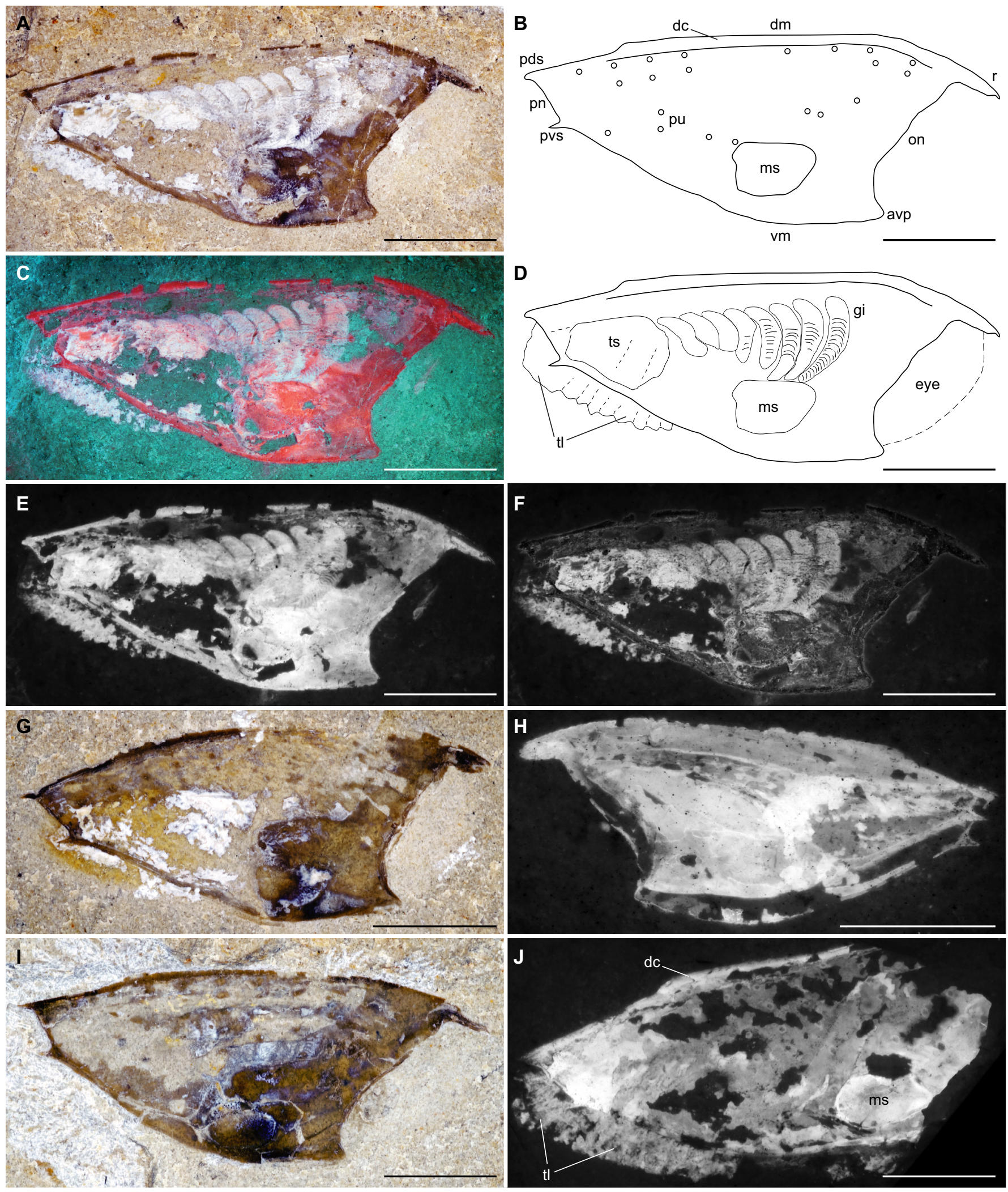
numerous fossil euarthropods, especially from limestone display a strong yellow autofluorescence. Pictures are digitally white-balanced to ease the visualisation of fluorescence.

Green fluorescence works on the same principle as UV fluorescence, in this case, the autofluorescence is light orange (Haug et al., 2009; Haug and Haug, 2011), and the green light has to be cancelled by an orange/red filter to allow the visualisation of the fluorescence. Once again, pictures are colour equilibrated to ease the visualisation of fluorescence.

\section{Systematic palaeontology}

Preliminary remarks. - In the early 1980s, three higher taxonomic levels were applied to thylacocephalans: the class Thylacocephala Pinna et al., 1982, class Conchyliocarida Secrétan, 1983, and order Concavicarida Briggs and Rolfe, 1983. Rolfe (1985) adopted the class Thylacocephala for the entire group, comprising two orders: Conchyliocarida and Concavicarida. This systematic classification was followed by Schram (1990), Schram et al. (1999), and Lange et al. (2001), although the genera included within each order are different in each paper. No family level designations have been made, except for the Austriocarididae Glaessner, 1931. Recently, Schram (2014) attempted, for the first time, to classify the thylacocephalans to the family level. However, Ehiro et al. (2015) considered that no clear definition was given to these families and it seems that further examination is necessary for family-level classification. Even if it is probably perfectible, we follow the classification proposed by Schram (2014).

THYLACOCEPHALA Pinna et al., 1982

Order CONCHYLIOCARIDA Secrétan, 1983

Family Dollocarididae Schram, 2014

Paradollocaris Charbonnier nov. gen. (Figs. 2-5).

Type species.-Paradollocaris vannieri Charbonnier nov. sp.

Etymology. - A combination of the Latin par, paris (close to) and Dollocaris Van Straelen, 1923. The gender of the genus is feminine.

Diagnosis. - Carapace with large optic notch limited by elongate, sharp rostrum and antero-ventral process; staple-like optic notch with straight, strongly inclined margin; rostrum with hook-like distal extremity; dorsal margin with crest extending above the rostrum and interrupted posteriorly; regular, convex ventral margin; large muscle scar; posterior margin with narrow notch limited by dorsal and ventral spines; hypertrophied eye; eight pairs of gills; robust prominent anterior appendages; posterior trunk somites bearing paddlelike limbs.

Discussion. - Paradollocaris is assigned to Dollocarididae based upon the following morphological characters: large optic notch limited by rostral and antero-ventral processes, hypertrophied eye, posterior notch with dorsal and ventral spines. The general morphology of the new genus is close to Dollocaris from the La Voulte-sur-Rhône Lagerstätte but some important differences can be reported. Paradollocaris differs from Dollocaris by its staple-like optic notch (strongly concave in Dollocaris), its elongate rostrum (short in Dollocaris), its regular convex ventral margin (more sinuous and with wide concavity before reaching antero-ventral process in Dollocaris), its subcircular muscle scar (ellipsoidal and prominent in Dollocaris), and the absence of longitudinal lateral carina (present in Dollocaris).

Paradollocaris differs from Paraostenia Secrétan, 1985 and Mayrocaris Polz, 1994 by the general morphology of its carapace. For instance, Paraostenia possesses a sub-rectangular carapace with a reduced rostrum and almost straight optic and posterior notches (staple-like optic notch with elongate rostrum in Paradollocaris), and a lateral carina associated to an undulate row of tubercles (absent in Paradollocaris). Mayrocaris Polz, 1994 shows a triangular ventral margin with a pronounced concavity before reaching the antero-ventral process (regular, convex ventral margin in Paradollocaris).

Paradollocaris differs also from Victoriacaris Hegna et al., 2014 and Polzia Hegna et al., 2014 by its staple-like optic notch and relatively narrow posterior notch (large and concave optical and posterior notches in Victoriacaris; concave optic notch and reduced posterior notch in Polzia), by its rostrum with hook-like distal extremity (beveled anterior spine in Victoriacaris; simple spiny rostrum in Polzia), and by its postero-ventral spine (rounded postero-ventral corner in Polzia).

Paradollocaris vannieri Charbonnier nov. sp. (Figs. 2-5). Etymology.-The specific epithet honours Jean Vannier, palaeontologist at the University of Lyon, France.

Type material.-Holotype MNHN.F.A57231, 16 paratypes MNHN.F.A57232-A57234, A57236-A57239, A57241, A57242, A57246, A57248, A57253, A57258 and MSNM i24983, i27858, i27859.

Type locality. - Hadjoula, Lebanon, Middle East.

Type age. - Late Cretaceous, Cenomanian.

Description.-Bivalved carapace, subtrapezoidal (holotype: length: $c a 17.5 \mathrm{~mm}$; height: $c a 7.5 \mathrm{~mm}$ ), laterally compressed, with very large optic notch and narrower posterior notch; convex dorsal margin separating carapace in two

Fig. 2. Paradollocaris vannieri Charbonnier nov. gen, nov. sp. from the Cenomanian of Hadjoula, Lebanon. A-F. holotype MNHN.F.A57231 showing carapace with preserved soft-parts, right lateral view: cross-polarized light (A), line drawing of carapace (B), green-orange fluorescence (C), interpretative line drawing of soft-parts (D); same as C, desaturated (E), or step wise desaturated (F). G. Paratype MNHN.F.A57232, carapace, right lateral view, cross-polarized light. H. Paratype MNHN.F.A57233, specimen showing the bivalved carapace, left lateral view, green-orange fluorescence desaturated. I. Paratype MNHN.F.A58238, carapace showing ornamentation composed of punctuations, right lateral view, cross-polarized light. J. Paratype MNHN.F.A57237, fragment of carapace showing posterior part of dorsal carina, right lateral view, greenorange fluorescence desaturated. Abbreviations: $a v p=$ antero-ventral process, $\mathrm{dc}=\mathrm{dorsal}$ carina, $\mathrm{dm}=\mathrm{dorsal}$ margin, gi $=$ lamellate gills, $\mathrm{ms}=$ muscle scar, on = optical notch, $\mathrm{pn}=$ posterior notch, $\mathrm{pu}=$ punctuation, $\mathrm{pds}=$ postero-dorsal spine, $\mathrm{pvs}=$ postero-ventral spine, $\mathrm{r}=$ rostrum, $\mathrm{tl}=$ paddle-like limbs or trunk limbs, $\mathrm{ts}=$ trunk somites, $\mathrm{vm}=$ ventral margin. Scale bars: $5 \mathrm{~mm}$. Line drawings: S. Charbonnier. Photographs: D. Audo (A, G, I) and J. Haug (C, E, F, H, J). 

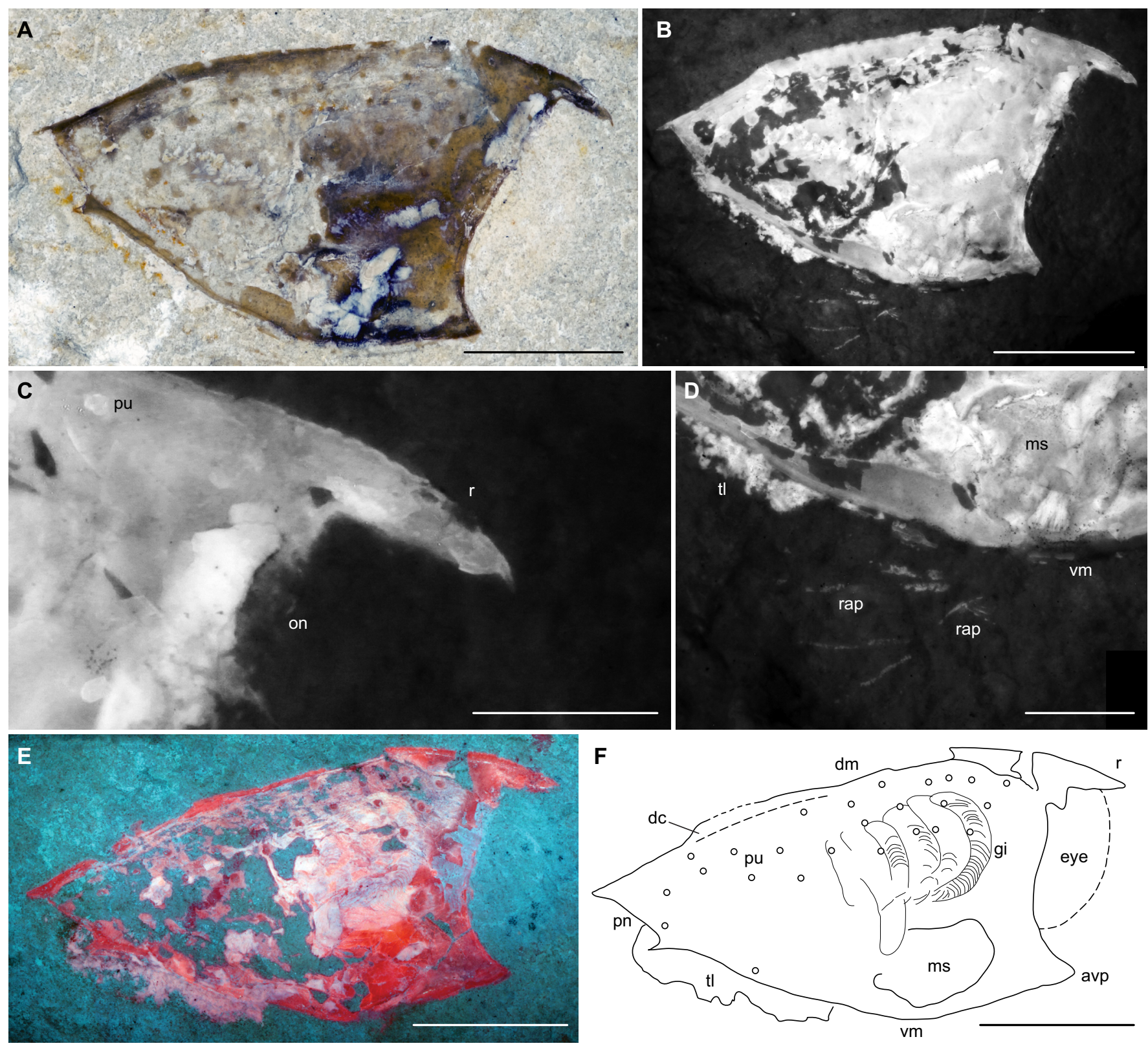

Fig. 3. Paradollocaris vannieri Charbonnier nov. gen, nov. sp. from the Cenomanian of Hadjoula, Lebanon. A-D. Paratype MNHN.F.A57234, carapace with slight longitudinal compression, right lateral view: cross-polarized light (A), note the punctuations of carapace; green-orange fluorescence desaturated (B-D), close-up of rostrum (C) and close-up of anterior appendages (poorly preserved) (D). E-F. Paratype MNHN.F. A57241, right lateral view: green-orange fluorescence $(\mathrm{E})$, interpretative line-drawing (F). Abbreviations: avp=antero-ventral process, $\mathrm{dc}=$ dorsal carina, $\mathrm{dm}=$ dorsal margin, gi=lamellate gills, $\mathrm{ms}=$ muscle scar, on $=$ optical notch, $\mathrm{pn}=$ posterior notch, $\mathrm{pu}=$ punctuation, $\mathrm{r}=$ rostrum, rap = prominent anterior appendages, $\mathrm{tl}=$ paddle-like limbs or trunk limbs, vm = ventral margin. Scale bars: $5 \mathrm{~mm}(\mathrm{~A}, \mathrm{~B}, \mathrm{E}, \mathrm{F})$ and $2 \mathrm{~mm}$ (C, D). Line drawing: S. Charbonnier. Photographs: D. Audo (A) and J. Haug (B-E).

identical valves, with a crest prolonged frontally by the rostrum and interrupted in the posterior first quarter of carapace; staple-like optic notch, limited by elongate, sharp rostrum and pointed antero-ventral process; optic notch with straight margin, inclined at about $50^{\circ}$ angle to longitudinal axis of carapace; elongate rostrum with hook-like distal extremity; regular, convex ventral margin divided into two sections of almost equal length: antero-ventral section slightly convex and postero-ventral one straight and inclined at about $130^{\circ}$ angle to longitudinal axis of carapace; muscle scar appearing as large subcircular protuberance (diameter: about one third of carapace height) in antero-ventral margin; muscle scar clearly in connexion with the basal level of anterior gills; posterior margin with relatively narrow, concave notch, limited by dorsal and ventral longitudinal spines; hypertrophied eye protruding through orbital notch; eight pairs of lamellate or phyllobranchiate gills; prominent anterior appendages (prehensile or raptorial appendages) poorly preserved but apparently very robust; posterior trunk somites bearing about 16 paddle-like limbs; ornamentation of carapace with circular 

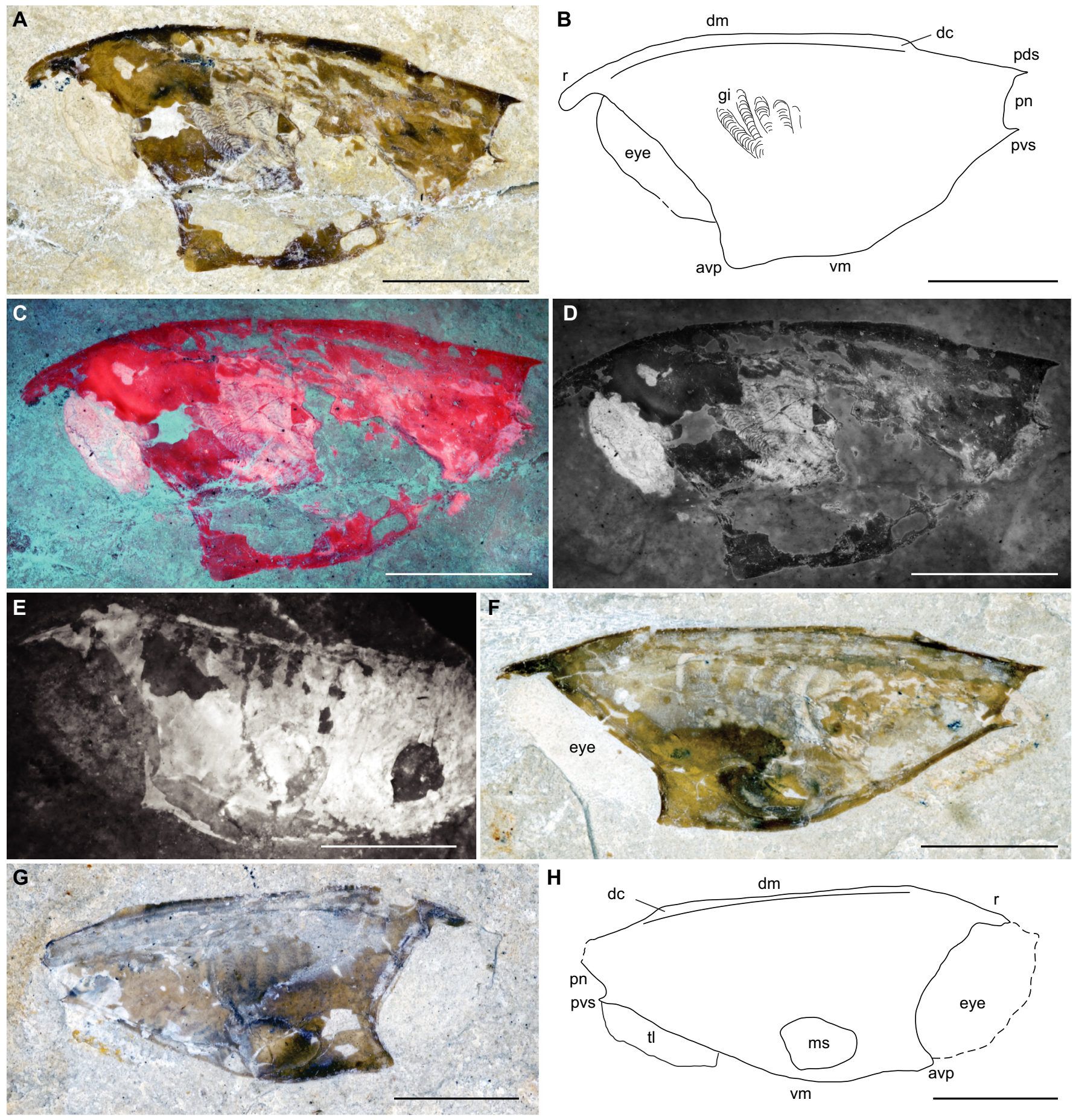

Fig. 4. Paradollocaris vannieri Charbonnier nov. gen, nov. sp. from the Cenomanian of Hadjoula, Lebanon. A-D. Paratype MNHN.F.A57236, showing carapace with preserved soft-parts, left lateral view: cross-polarized light (A), interpretative line drawing of carapace and soft-parts (B), green-orange fluorescence (C), green-orange fluorescence step-wise desaturated (D). E. Paratype MSNM i24983, left lateral view, green-orange fluorescence step-wise desaturated. F. Paratype MNHN.F.A57248 showing carapace and soft-parts (eye and lamellate gills), left lateral view, cross-polarized light. G-H. Paratype MNHN.F.A57246, carapace, right lateral view (G) and line drawing $(H)$. Abbreviations: avp=anteroventral process, $\mathrm{dc}=$ dorsal carina, $\mathrm{dm}=$ dorsal margin, gi=lamellate gills, $\mathrm{ms}=$ muscle scar, on $=$ optical notch, pn=posterior notch, $\mathrm{pu}=$ punctuation, $\mathrm{pds}=$ postero-dorsal spine, $\mathrm{pvs}=$ postero-ventral spine, $\mathrm{r}=$ rostrum, $\mathrm{tl}=$ paddle-like limbs or trunk limbs, $\mathrm{vm}=\mathrm{ventral}$ margin . Scale bars: $5 \mathrm{~mm}$. Line drawings: S. Charbonnier. Photographs: D. Audo (A, F, G) and J. Haug (C-E). 

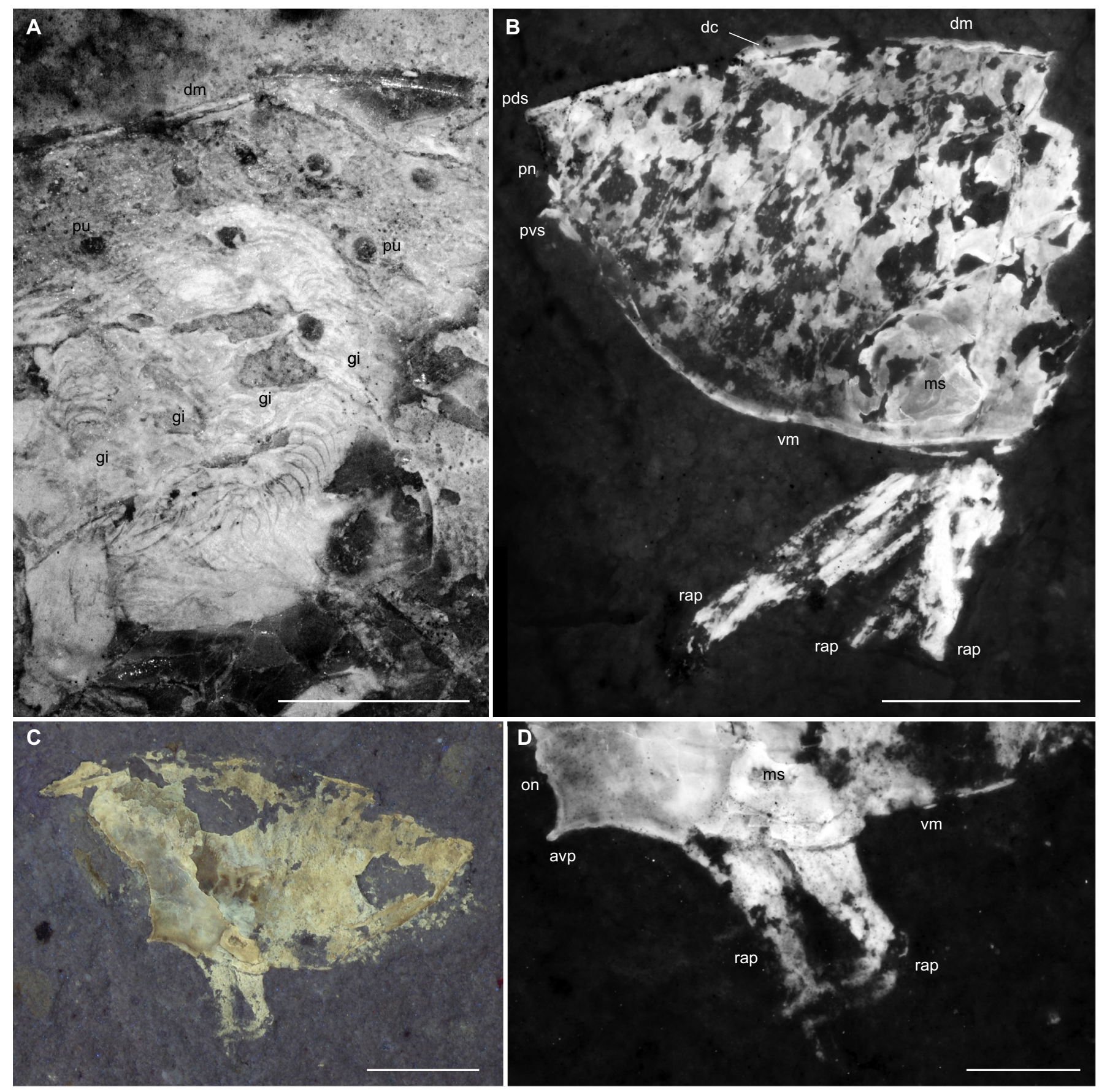

Fig. 5. Paradollocaris vannieri Charbonnier nov. gen, nov. sp. from the Cenomanian of Hadjoula, Lebanon. A. Paratype MNHN.F.A57241, close-up of carapace showing punctuations and lamellate gills, green-orange fluorescence step-wise desaturated. B. Paratype MNHN.F.A57239, posterior part of specimen showing fragments of robust prominent anterior appendages, right lateral view, green-orange fluorescence desaturated. C-D. Paratype MSNM i27859, left lateral view, carapace with fragments of prominent anterior appendages, UV light (C), and closeup of prominent anterior appendages (D), green-orange fluorescence desaturated. Abbreviations: avp $=$ antero-ventral process, dc $=$ dorsal carina, $\mathrm{dm}=$ dorsal margin, gi $=$ lamellate gills, $\mathrm{ms}=$ muscle scar, on $=$ optical notch, $\mathrm{pn}=$ posterior notch, $\mathrm{pu}=$ punctuation, pds $=$ postero-dorsal spine, pvs = postero-ventral spine, rap= prominent anterior appendages, vm= ventral margin. Scale bars: $2 \mathrm{~mm}(\mathrm{~A}, \mathrm{D})$ and $5 \mathrm{~mm}(\mathrm{~B}, \mathrm{C})$. Photographs: J. Haug (A, B, C) and P. Loubry (C).

punctuations possibly arranged in a pattern, probably irregular vertical rows (not clearly visible due to the preservation).

Discussion - Examined specimens of Paradollocaris vannieri vary in proportion, some are slightly longer (Fig. 2A-F), some shorter (Fig. 3A-F). Close observations of shorter specimens reveal in some cases wrinkles on the surface of the fossil. These wrinkles seem to indicate that the fossil was compressed along its longitudinal axis, resulting in a small deformation. Taking into account that some of the variations in proportion within our sample are linked to deformation, 

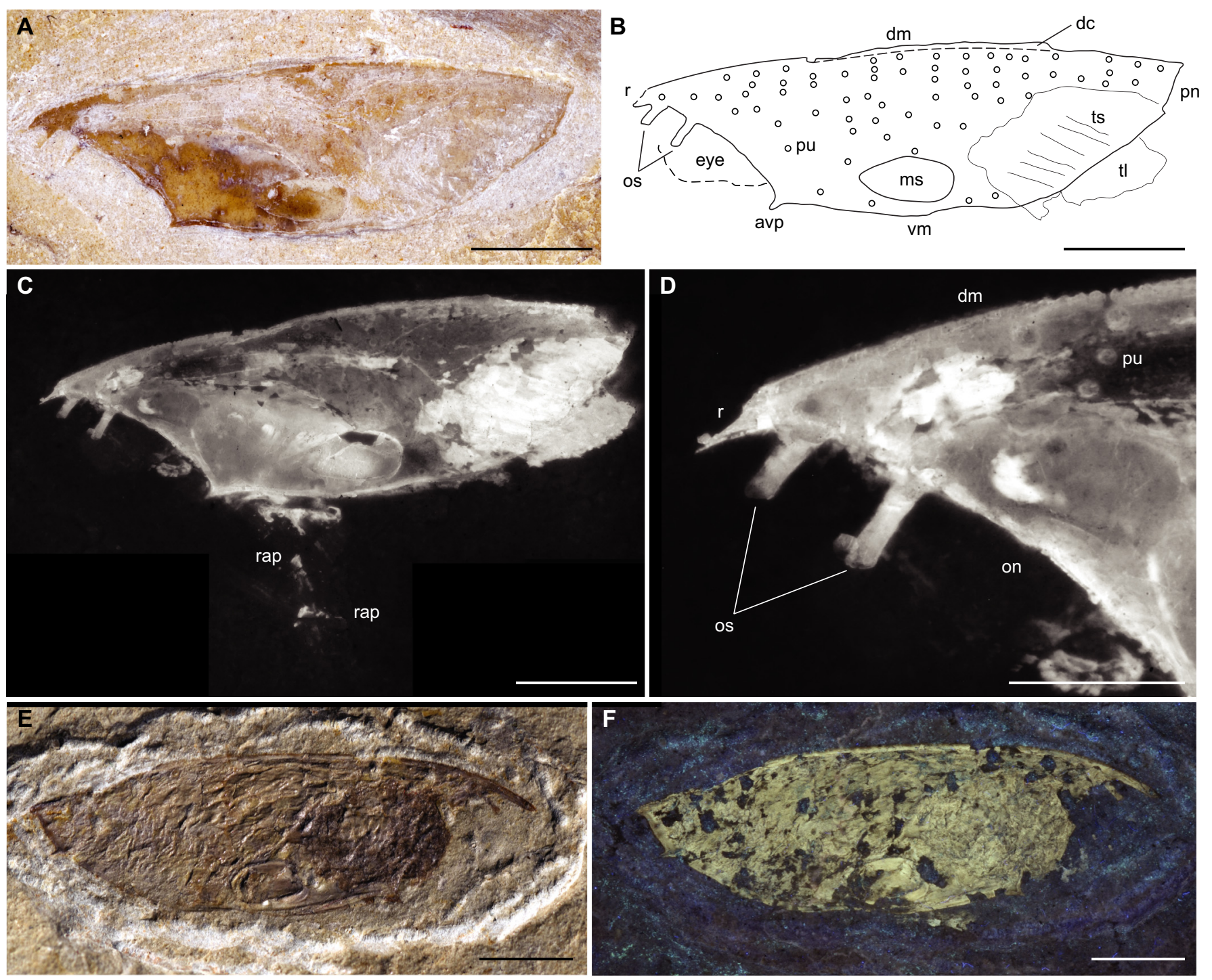

Fig. 6. Thylacocaris schrami Audo and Charbonnier nov. gen, nov. sp. from the Cenomanian of Hadjoula, Lebanon. A-D. Holotype MNHN.F. A57240, left lateral view, cross-polarized light (A), line-drawing of carapace, and soft-parts (B), carapace and fragments of anterior prehensile appendages, green-orange fluorescence desaturated $(\mathrm{C})$, close-up of optical notch showing broken rostrum and two optical spines, green-orange fluorescence desaturated (D). E-F. Paratype MSNM i24785, carapace, right lateral view, natural light (E), UV light (F). Abbreviations: $\mathrm{avp}=$ antero-ventral process, $\mathrm{dc}=$ dorsal carina, $\mathrm{dm}=$ dorsal margin, $\mathrm{ms}=$ muscle scar, on $=$ optical notch, $\mathrm{os}=$ optical spine, $\mathrm{pn}=$ posterior notch, $\mathrm{pu}=$ punctuation, $\mathrm{rap}=$ prominent anterior appendages, $\mathrm{tl}=$ paddle-like limbs or trunk limbs, $\mathrm{ts}=$ trunk somites, $\mathrm{vm}=$ ventral margin. $\mathrm{Scale}$ bars: $5 \mathrm{~mm}$ (A-C, E, F) and $2 \mathrm{~mm}$ (D). Line drawing: S. Charbonnier. Photographs: D. Audo (A), J. Haug (C, D) and L. Cazes (E-F).

and without other characters to distinguish the various specimens, we consider that our sample is monospecific. However, some of the observed variations may also have a biological cause and correspond to intraspecific variations, for instance sexual dimorphism. It is unfortunately not possible to test these ideas considering the preservation of the specimens and our current poor understanding of the thylacocephalan biology.

Thylacocaris Audo and Charbonnier nov. gen. (Figs. 6-8). Type species. - Thylacocaris schrami Audo and Charbonnier nov. sp.

Etymology.-Derived from the name of the class Thylacocephala. The gender of the genus is feminine.
Diagnosis. - Elongate carapace with lateral outline almost elliptical; large optic notch limited by, elongate, sharp rostrum and short antero-ventral process; slightly concave optic notch with straight, strongly inclined margin, bearing two strong optic spines; dorsal margin with crest extending above the rostrum and interrupted posteriorly; regular, slightly convex ventral margin; large muscle scar located medially of ventral margin; posterior margin with narrow notch limited by dorsal and ventral spines; hypertrophied eye; robust prominent anterior appendages; posterior trunk somites bearing numerous paddle-like limbs.

Discussion.-Thylacocaris is assigned to Dollocarididae based upon the following morphological characters: large optic notch limited by rostral and antero-ventral processes, 

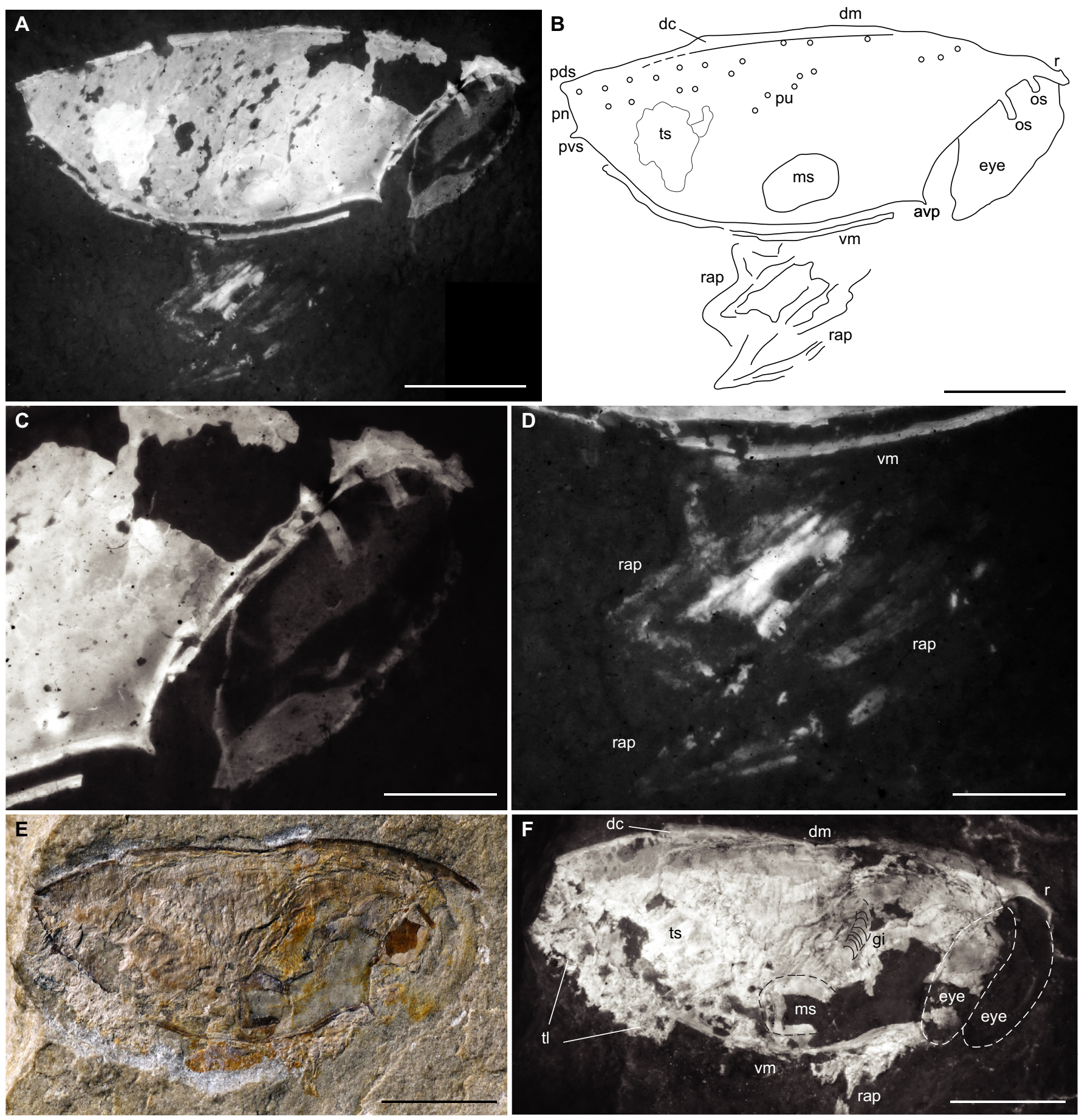

Fig. 7. Thylacocaris schrami Audo and Charbonnier nov. gen, nov. sp. from the Cenomanian of Hadjoula, Lebanon. A-D. Paratype MNHN.F. A57235, right lateral view, green-orange light desaturated, subcomplete specimen showing carapace, eye, and prominent anterior appendages (A), interpretative line drawing (B), close-up of optical notch with well-preserved eye, and two optic spines (C), close-up of anterior appendages (D). E-F. Paratype MSNM i25125, carapace, eyes and fragments of anterior appendages, natural light (E), green-orange light desaturated (F). Abbreviations: $\mathrm{avp}=$ antero-ventral process, $\mathrm{dc}=$ dorsal carina, $\mathrm{dm}=$ dorsal margin, gi $=$ lamellate gills, $\mathrm{ms}=$ muscle scar, os $=\mathrm{optical}$ spine, $\mathrm{pn}=$ posterior notch, $\mathrm{pu}=$ punctuation, $\mathrm{pds}=$ postero-dorsal spine, $\mathrm{pvs}=$ postero-ventral spine, $\mathrm{r}=$ rostrum, rap $=$ prominent anterior appendages, $\mathrm{tl}=$ paddle-like limbs or trunk limbs, ts = trunk somites, vm= ventral margin. Scale bars: $5 \mathrm{~mm}(\mathrm{~A}, \mathrm{~B}, \mathrm{E}, \mathrm{F})$ and $2 \mathrm{~mm}(\mathrm{D})$. Line drawing: S. Charbonnier. Photographs: J. Haug (A, C, D, F) and L. Cazes (E). 

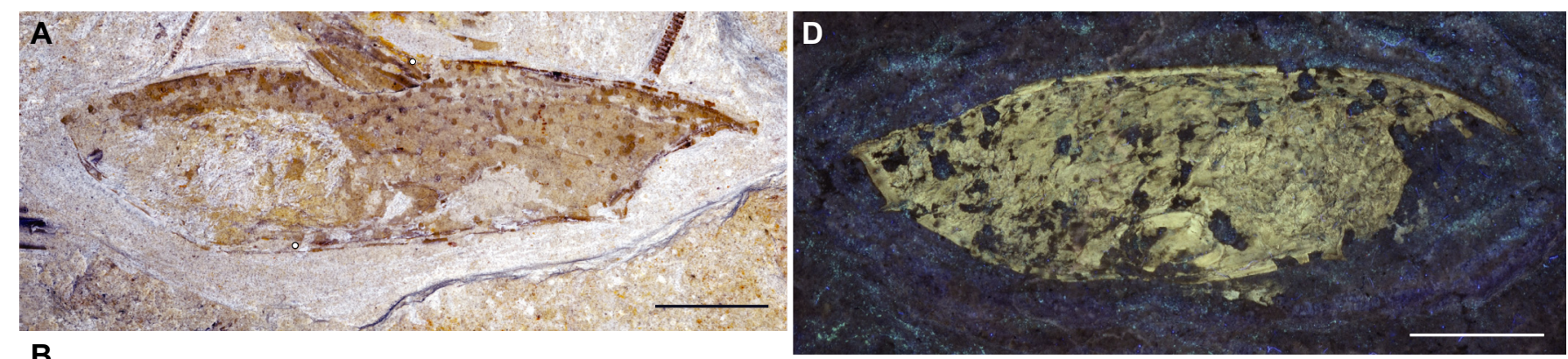

B
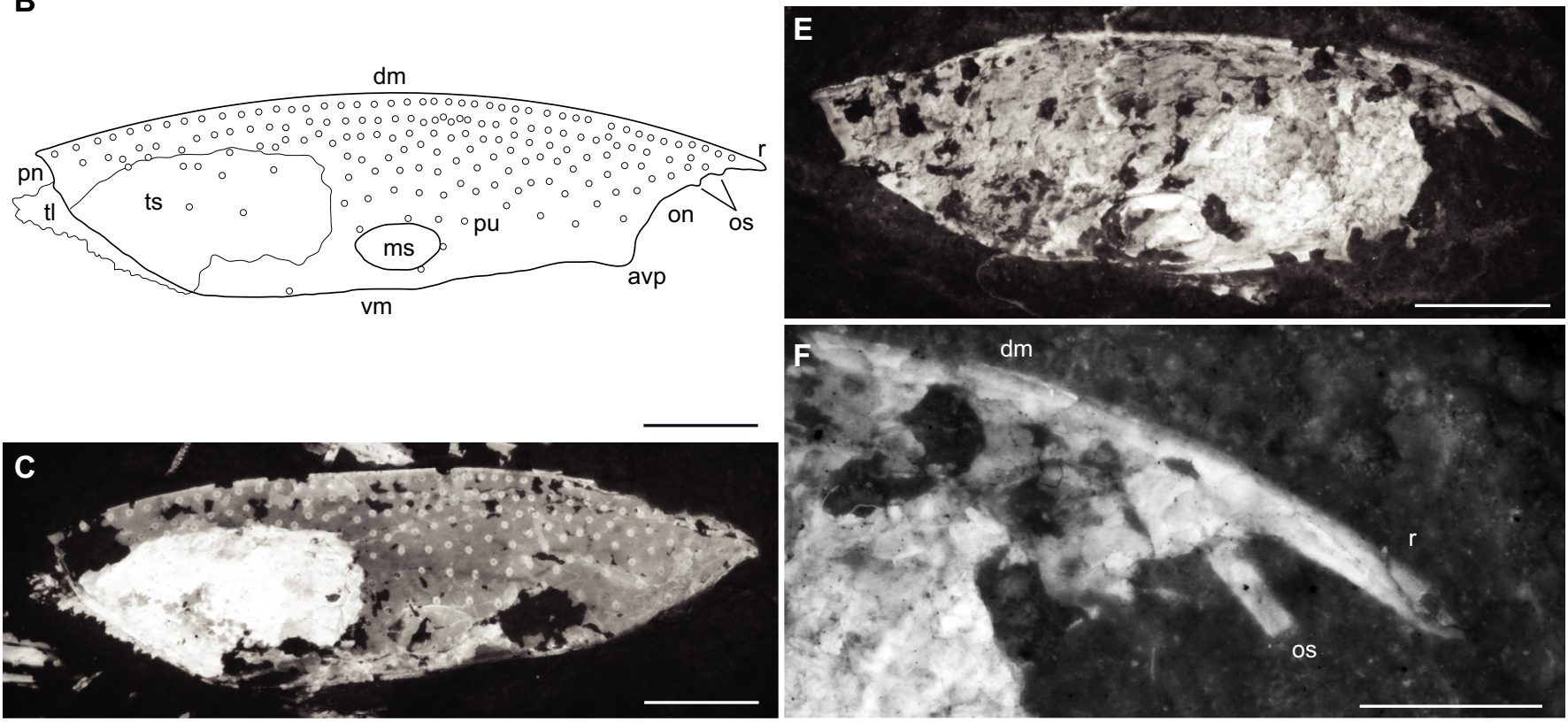

Fig. 8. Thylacocaris schrami Audo and Charbonnier nov. gen, nov. sp. from the Cenomanian of Hadjoula, Lebanon. A-C. Paratype MNHN.F. A57244, carapace, right lateral view, natural light (A), line drawing (B), green-orange light desaturated, before preparation (C). D-F. Paratype MSNM i24785, carapace, right lateral view, UV light (D), green-orange light desaturated (E), close-up of rostrum (F). Abbreviations: $\mathrm{avp}=$ antero-ventral process, $\mathrm{dm}=$ dorsal margin, $\mathrm{ms}=$ muscle scar, on $=$ optical notch, os $=$ optical spine, $\mathrm{pn}=$ posterior notch, $\mathrm{pu}=$ punctuation, $\mathrm{r}=$ rostrum, $\mathrm{tl}=$ paddle-like limbs or trunk limbs, ts = trunk somites, $\mathrm{vm}=$ ventral margin. Scale bars: $5 \mathrm{~mm}(\mathrm{~A}-\mathrm{E})$ and $2 \mathrm{~mm}(\mathrm{~F})$. Line drawing: M. Lasseron. Photographs: D. Audo (A), J. Haug (C, E, F) and L. Cazes (D).

hypertrophied eye, posterior notch with dorsal and ventral spines. Thylacocaris differs from Dollocaris and Paradollocaris by its longitudinally elongate carapace, its slightly concave optic notch (strongly concave in Dollocaris and staple-like in Paradollocaris), its elongate rostrum (short in Dollocaris), its regular, almost straight ventral margin (more sinuous and with wide concavity before reaching antero-ventral process in Dollocaris and convex in Paradollocaris), its large muscle scar (ellipsoidal and prominent in Dollocaris), and the absence of longitudinal lateral carina (present in Dollocaris).

Thylacocaris differs from Paraostenia Secrétan, 1985 and Mayrocaris Polz, 1994 by the general morphology of its carapace (ellipsoidal in lateral outline). For instance, Paraostenia exhibits sub-rectangular carapace bearing optic and posterior notches almost straight and without developed rostrum (concave optic notch with elongate rostrum in Thylacocaris), and a lateral carina associated to an undulate row of tubercles (absent in Thylacocaris). Mayrocaris Polz, 1994 shows a triangular ventral margin with a pronounced concavity before reaching the antero-ventral process (regular, almost straight ventral margin in Thylacocaris).
Thylacocaris differs also from Victoriacaris Hegna et al., 2014 and Polzia Hegna et al., 2014, mainly by the elongate shape of its carapace (subtrapezoidal in Victoriacaris and in Polzia), by its elongate rostrum (beveled anterior spine in Victoriacaris; simple spiny rostrum in Polzia), and by its optic spines (absent in Victoriacaris and in Polzia).

Thylacocaris schrami Audo and Charbonnier nov. sp. (Figs. 6-8).

Etymology.-The specific epithet honours Frederick Schram, palaeontologist at the Burke Museum, University of Washington, USA.

Type material. - Holotype MNHN.F.A57240, five paratypes MNHN.F.A57235, A57244, and MSNM i24785, i25125, i26785.

Type locality. - Hadjoula, Lebanon, Middle East.

Type age.-Late Cretaceous, Cenomanian.

Description.-Bivalved carapace, laterally compressed, longitudinally elongate (holotype: length: $c a 20.8 \mathrm{~mm}$; height: ca $5.6 \mathrm{~mm}$ ), almost elliptical in lateral outline, with very large optic notch and narrower posterior notch; convex dorsal 
margin separating carapace in two identical valves, with a crest prolonged frontally by the rostrum and interrupted in the posterior first quarter of carapace; concave optic notch, limited by elongate, sharp rostrum and pointed antero-ventral process; optic notch with straight margin, inclined at about $40^{\circ}$ angle to longitudinal axis of carapace, bearing in the dorsal part two strong spines downward inclined (lower spine longer than upper spine); elongate rostrum with pointed distal extremity; regular, convex ventral margin divided into two sections of almost equal length: antero-ventral section almost straight and horizontal, and postero-ventral one straight and inclined at about $120^{\circ}$ angle to longitudinal axis of carapace; muscle scar appearing as large subcircular protuberance (diameter: about one third of carapace height) in antero-ventral margin; posterior margin with narrow, staple-like notch, limited by dorsal and ventral longitudinal spines; hypertrophied eye protruding through orbital notch; lamellate gills, poorly visible in all available specimens; prominent anterior appendages (prehensile or raptorial appendages) poorly preserved but apparently robust; posterior trunk somites bearing paddle-like limbs of unassessable number (numerous, probably about 16 ?); ornamentation of carapace with circular punctuations uniformly arranged.

Discussion. - In paratype MNHN.F.B18836 of Thylacocephalus cymolopos, Lange et al. (2001) interpreted articulated appendages found in the optic notch adjacent to the rostrum, as evidence of small antennulae and antennae. Careful examination of this specimen leads us to a different conclusion: the articulation of these two structures is only apparent and linked to the preservation of the cuticle of the thin carapace. These structures are similar to those observed in the optic notch of Thylacocaris schrami, and most probably correspond to optic spines protecting the hypertrophied eyes. Based on the interpretation proposed by Lange et al. (2001), Schram (2014) supposed that the compound eyes of Thylacocephalus might be not hypertrophied. Our new interpretation, coupled with the evidence of large eyes in Thylacocaris, makes the presence of large eyes in Thylacocephalus possible, and questions its familial placement within Microcarididae Schram, 2014. Comparison with Thylacocaris suggests Thylacocephalus could instead correspond to a Dollocarididae.

Order CONCAVICARIDA Briggs and Rolfe, 1983

Family Protozoeidae Schram, 2014

Globulocaris Teruzzi and Charbonnier nov. gen. (Fig. 9).

Type species.-Globulocaris garassinoi Teruzzi and Charbonnier nov. sp.

Etymology. - Derived from the Latin globulosus (spherical, rounded), alluding to the globular shape of the carapace. The gender of the genus is feminine.

Diagnosis. - Small globular carapace, about twice as long as deep; convex dorsal margin prolonged anteriorly by the rostrum and interrupted posteriorly at level of very short concave notch anterior to the postero-dorsal spine; slightly concave optic notch, limited by sharp and short rostrum and rounded antero-ventral process; ventral margin rounded in lateral outline; posterior margin limited by strong posterodorsal spine and rounded postero-ventral process; one short posterior spine immediately under postero-dorsal spine, both forming narrow and concave notch; eye relatively large.
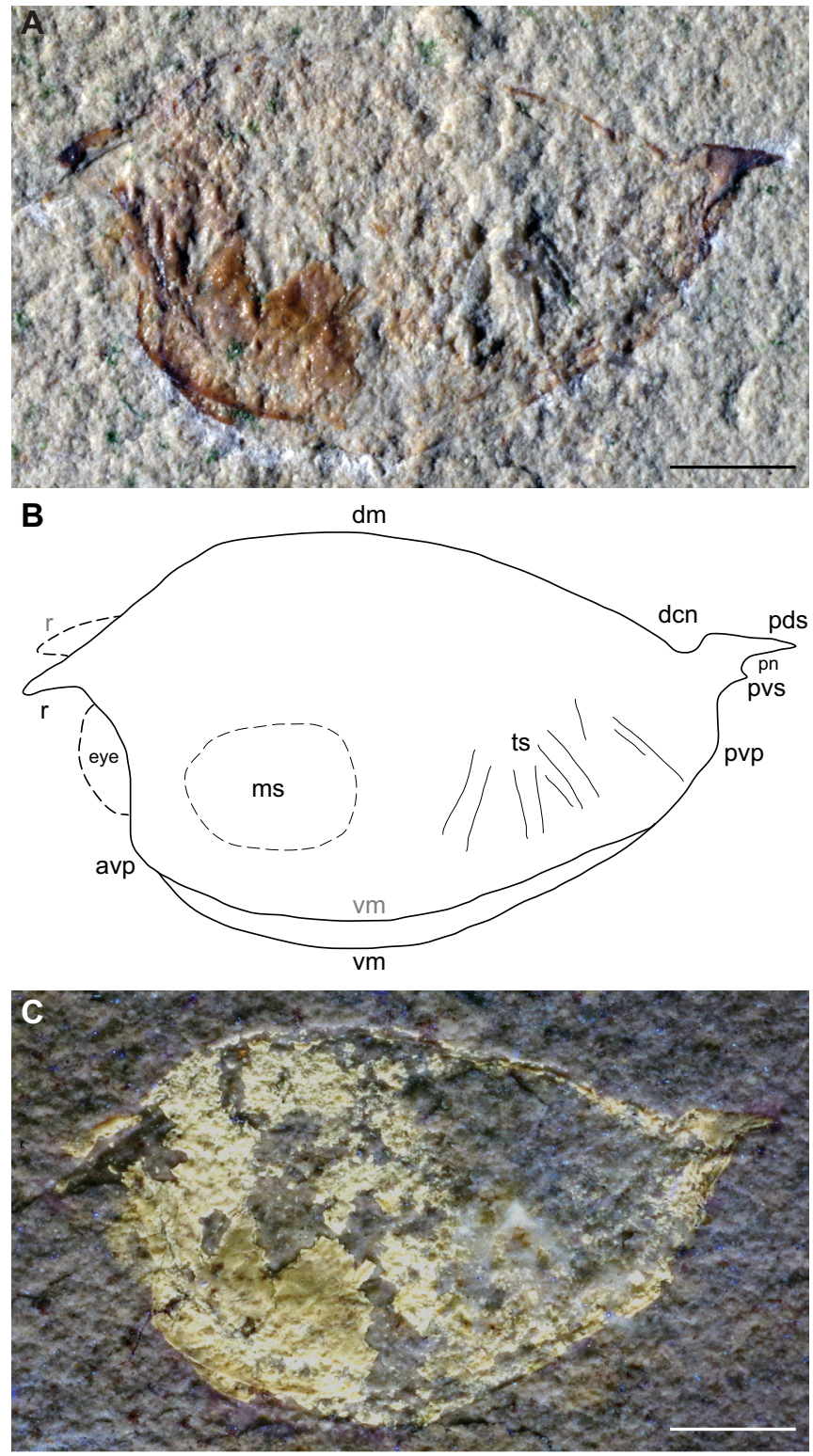

Fig. 9. Holotype MSNM i20655 of Globulocaris garassinoi Teruzzi and Charbonnier nov. gen, nov. sp. from the Cenomanian of Hakel, Lebanon. A. Carapace, left lateral view, natural light. B. Interpretative line drawing. C. Image with inverted colours. Abbreviations: $\mathrm{avp}=$ antero-ventral process, $\mathrm{dm}=$ dorsal margin, $\mathrm{den}=$ dorsal concave notch, $\mathrm{ms}=$ muscle scar, $\mathrm{pn}=$ posterior notch, $\mathrm{pds}=$ posterodorsal spine, $p v s=$ postero-ventral spine, $r=$ rostrum, ts $=$ trunk somites, vm=ventral margin. Scale bars: $2 \mathrm{~mm}$. Line drawing: S. Charbonnier. Photographs: G. Teruzzi.

Discussion.-Globulocaris is assigned to Protozoeidae based upon the following morphological characters: small carapace with distinct dorsal notch of posterior portion of carapace anterior to strong postero-dorsal spine, and optic notch not particularly concave with rounded antero-ventral process. Globulocaris differs from Protozoea Dames, 1886, Pseuderichthus Dames, 1886, and Hamaticaris nov. gen. by its globular carapace (subtrapezoidal in Protozea, Pseuderichthus, and Hamaticaris), its short simple rostrum (very elongate 
in Protozoea; elongate with one infra-rostral spine in Pseuderichthus and Hamaticaris), its dorsal margin with very short concave notch anterior to the postero-dorsal spine (smooth and regular in Protozoea; large notch limited by dorsal spine in Pseuderichthus), and its narrow posterior notch limited by spines (absent in Protozoea and Hamaticaris). Globulocaris differs also from Victoriacaris Hegna et al., 2014 and Polzia Hegna et al., 2014, mainly by the globular shape of its carapace (subtrapezoidal in Victoriacaris and Polzia), by its short rostrum (beveled anterior spine in Victoriacaris), and by its narrow posterior notch (very large in Victoriacaris; almost absent in Polzia).

Globulocaris garassinoi Teruzzi and Charbonnier nov. sp. (Fig. 9).

Etymology.-The specific epithet honours Alessandro Garassino, formerly a palaeontologist at the Museo di Storia Naturale di Milano, Italy.

Type material.-Holotype by monotypy MSNM i20655.

Type locality. - Hakel, Lebanon, Middle East.

Type age.-Late Cretaceous, Cenomanian.

Description.-Bivalved carapace; small globular, about twice as long as deep (length: $12 \mathrm{~mm}$; height: $7 \mathrm{~mm}$ ); convex dorsal margin prolonged anteriorly by the rostrum (split in the present specimen: see line drawing) and interrupted posteriorly at level of very short concave notch anterior to the posterodorsal spine; dorsal margin almost horizontal between the short concave notch and the postero-dorsal spine; optic notch with slightly concave margin, inclined at about $90^{\circ}$ angle to longitudinal axis of carapace, limited by sharp and short rostrum and rounded antero-ventral process; ventral margin rounded in lateral outline (split in the present specimen: see line drawing); muscle scar appearing as large circular protuberance (diameter: $3 \mathrm{~mm}$ ) in antero-ventral margin; posterior margin limited by strong postero-dorsal spine and rounded postero-ventral process; one short posterior spine immediately under postero-dorsal spine, both forming narrow and concave posterior notch; eye poorly preserved but relatively large; prominent anterior appendages not preserved; posterior trunk somites poorly preserved.

Hamaticaris Charbonnier nov. gen. (Fig. 10).

Type species. - Protozoea damesi Roger, 1946.

Etymology.-Derived from the Latin hamatus (hooked), alluding to the hooked rostrum. The gender of the genus is feminine.

Diagnosis. - Carapace, trapezoidal in lateral outline, with very elongate spiny rostrum and postero-dorsal spine; rostral spine directed slightly upward, accompanied by small anteriorly oriented hook ventral to its base; antero-ventral process with small rounded projection present just below large optic notch; dorsal margin with very short concave notch anterior to the postero-dorsal spine; bifurcate or Y-shaped arrangement of ridges on central aspect of carapace; three parallel, longitudinal rows of punctuations on dorsal aspect of carapace surface; gracile anterior appendages (prehensile appendages); eight posterior trunk somites bearing eight paddle-like limbs.

Preliminary remarks. - Dames (1886) erected the genera Protozoea (with P. hilgendorfi as type species) and Pseuderichthus (with Ps. cretaceus as type species). The same fossils had already been described but not named by Hilgendorf
(1885), who drew direct comparisons between these fossils and several larvae of extant crustaceans. Dames (1886) also thought that these fossils represented larval forms of unknown genera of stomatopods. This idea that Protozoea and Pseuderichthus were stomatopod larvae was later strongly endorsed by Van Straelen (1938). Later, Roger (1946) recognized the new form Protozoea damesi and concluded that the two species of Protozoea had to represent probably remains of adult branchiopods. The possibility these genera may be thylacocephalans was first suggested by Arduini et al. (1980: 369) and seconded by Pinna et al. (1982: 481). Schram et al. (1999) reviewed the thylacocephalan fauna from Lebanon providing very detailed descriptions. However, these authors maintained Roger's species in Protozoea whereas the respective carapaces of Protozoea hilgendorfi and $P$. damesi are clearly different and lead us to propose the new genus Hamaticaris.

Discussion.-Hamaticaris is assigned to Protozoeidae based upon the following morphological characters: very elongate rostrum, carapace much longer than deep, with elongate postero-dorsal spine, and gracile anterior prehensile appendages. Hamaticaris differs from Protozoea Dames, 1886, Pseuderichthus Dames, 1886, and Globulocaris by its trapezoidal carapace (globular in Globulocaris), its very elongate rostrum with hooked infra-rostral spine (very elongate and smooth in Protozoea, short with simple infrarostral spine in Pseuderichthus, short and simple in Globulocaris), its dorsal margin with very short concave notch anterior to the postero-dorsal spine (smooth and regular in Protozoea; large notch limited by dorsal spine in Pseuderichthus), its antero-ventral process with small rounded projection (absent in three other genera), its regular posterior margin (with narrow posterior notch limited by spines in Pseuderichthus and Globulocaris), and its Y-shaped arrangement of ridges on central aspect of carapace (absent in three other genera). Hamaticaris differs also from Victoriacaris Hegna et al., 2014 and Polzia Hegna et al., 2014, mainly by its very elongate rostrum and postero-dorsal spine (beveled anterior spine in Victoriacaris, short rostrum in Polzia), and by its simple posterior margin (with large posterior notch in Victoriacaris).

Hamaticaris damesi (Roger, 1946) nov. comb. (Fig. 10). Protozoe damesi - Roger (1946: 59-61, fig. 49, pl. 6, figs 7-9).

Protozoe damesi - Pinna et al. (1982: 481). Arduini and Pinna(1989: 5, 32, fig. p.5).

Protozoea damesi - Schram et al. (1999: 778-784, fig. 3, pl. 4 and 5).

Type material. - Lectotype MNHN.F.B18843 (figured by Roger 1946: pl. 6, fig. 7); 24 paralectotypes: MNHN.F.B18842 (figured by Roger 1946: pl. 6, fig. 8), B18844, B18885 (figured by Roger 1946: pl. 6, fig. 9), A30652-A30669, A30672, A50518, A50523.

The composition of the original type material has been modified and debated by several authors. Schram et al. (1999) stated that Roger (1946) proposed an extensive description of the species but "without referring to specimen numbers". They also designated specimen MNHN.F.B18842, illustrated by Roger (1946: pl. 6, fig. 8), to be the lectotype, which is then considered to be "the best of the surviving specimens. Of the 
original three specimens, the counterpart of the holotype is lost". However, careful examination of the original text reveals that the type material was composed of almost 60 specimens from Sahel Alma and that Roger (1946) did not selected a holotype. Another confusion comes from Arduini and Pinna (1989: 5, caption of right figure) who fixed specimen MNHN. F.B18843, illustrated by Roger (1946: pl. 6, fig. 7), as lectotype (ICZN, 1999: art. 74.6). Thus, the lectotype proposed by Schram et al. (1999) is not valid. In conclusion, only 25 specimens from the original type material are still housed in the palaeontological collections of the MNHN, Paris.

Type locality. - Sahel Alma, Lebanon, Middle East.

Type age. - Late Cretaceous, Santonian.

Description.-Bivalved carapace, trapezoidal in lateral outline, elongate (lectotype: length: ca $12 \mathrm{~mm}$; height: $c a$ $4 \mathrm{~mm}$ ); very elongate rostrum (length about one-quarter the length of the central part of the carapace); bending at acute angle from the slightly convex dorsal margin, directed slightly upward, accompanied at its base by small hooked infra-rostral spine ("crochet" in Roger, 1946, or "hook" in Schram et al., 1999) pointing anteriorly; very elongate postero-dorsal spine (length about one-quarter the length of the central part of the carapace), prolonging dorsal margin; slightly convex dorsal margin, with small concave notch anterior to the postero-dorsal spine; large, concave optic notch limited by rostral hook and rounded antero-ventral process; antero-ventral process with small rounded, ventrally directed projection (or "knob" in Schram et al., 1999 of the marginal carina, followed directly by a very slight notch; ventral margin parallel to dorsal margin and making a $45^{\circ}$ angle upwards to meet the base of the postero-dorsal spine at an abrupt angle; straight posterior margin; bifurcate or Y-shaped arrangement of ridges on central part of carapace (after Schram et al., 1999: "the stem and dorsal fork of the $\mathrm{Y}$ is a long, $\mathrm{V}$-like ridge flanked by shallow grooves, and the ventral fork is a much shorter and shallower ridge extending posteriorly towards the ventral margin. The pits in this region also seem to form rows. One row of about four or five pits closely parallels the ventral carina, and another pit row is roughly parallel with the ridges of the Y-shaped structure, but at some small distance from it"); ornamentation of carapace composed of three parallel, longitudinal rows of punctuations, lying on dorsal part, just above Y-shaped ridges; dorsal row with about 40 punctuations; median and ventral row with about 27 punctuations; eye poorly preserved but relatively large; about eight pairs of gills; three gracile anterior prehensile appendages; eight posterior trunk somites bearing eight paddle-like limbs (description largely inspired by Schram et al., 1999).

Family Microcarididae Schram et al., 1999

Keelicaris Teruzzi and Charbonnier nov. gen. (Fig. 11).

Type species. - Keelicaris deborae Teruzzi and Charbonnier nov. sp.

Etymology. - Derived from the Middle English kele (keel: lowest and principal timber of a ship), alluding to the peculiar shape of the carapace.

Diagnosis.-Keel-shaped carapace with very narrow ventral margin and convex dorsal margin; short rostrum; longitudinal lateral carina in median part of carapace; muscle scar inserted at base of restricted ventral margin; very elongate, arcuate posterior margin; large, sub-rectilinear optical notch; ornamentation composed of subparallel vertical rugations or terraces ("ribs"), regularly spaced from dorsal margin, and terminating in restricted ventral region, leaving just smooth muscle scar region; one longitudinal row of punctuations under dorsal margin.

Discussion. - The peculiar keel-shaped carapace of Keelicaris with its deep, narrow ventral margin is quite unique with respect to any known thylacocephalan carapace. It can remind the outline of Pseuderichthus or Victoriacaris, which carapaces are narrower in the ventral area. However, in Keelicaris, the ventral margin is one eighth less long than the dorsal margin, while in Victoriacaris it is half less long than the dorsal margin, and in Pseuderichthus it is a third less long than the dorsal margin (anterior and posterior spines included). Both Pseuderichthus and Victoriacaris have no surface ornamentation except punctuations in Pseuderichthus.

After several comparisons, Keelicaris is assigned to Microcarididae based upon its carapace surface with rugations or terraces shared with Microcaris Pinna, 1974, Atropicaris Arduini and Brasca, 1984, Rugocaris Tintori et al., 1986, Ferrecaris Calzada and Mañé, 1993, Thylacocephalus Lange et al., 2001, and Kitakamicaris Ehiro et al., 2015. Keelicaris differs from all these genera by the general morphology of its carapace. Concerning the ornamentation, the rugations in Keelicaris are strong and subparallel, deviated at level of the lateral median carina, convergent and interrupted in the muscle scar area (sinuous, imbricated rugations present on all the carapace surface in Atropicaris, Microcaris and Kitakamicaris; sinuous, subparallel rugations present on all the carapace surface in Ferrecaris; rounded, subparallel, widely spaced rugations in Rugocaris; alternating ribs and grooves associated to rows of punctuations, interrupted in ventral region - muscle scar area - in Thylacocephalus). The interruption of rugations in the muscle scar area is shared only by Keelicaris and Thylacocephalus but the shape of the ventral margin is very different.

Keelicaris deborae Teruzzi and Charbonnier nov. sp. (Fig. 11).

Etymology. - The specific epithet honours Debora Affer who prepared more than 1000 specimens of thylacocephalans from the Sahel Alma Lagerstätte housed at the Museo di Storia Naturale di Milano, Italy.

Type material. - Holotype by monotypy MSNM i 27356.

Type locality. - Sahel Alma, Lebanon, Middle East.

Type age.-Late Cretaceous, Santonian.

Description. - Keel-shaped carapace (length: ca $40 \mathrm{~mm}$ : height: $17.5 \mathrm{~mm}$ ) characterized by deep, subtrapezoidal, ventral margin; short rostrum; very short, narrow ventral margin of about one eighth of the dorsal margin length and located in the anterior half of carapace; rounded muscle scar, inserted at base of restricted ventral margin; convex dorsal margin (posterior end damaged), anteriorly prolonged by short rostrum; one longitudinal row of punctuations under dorsal margin; very elongate, concave and arcuate posterior margin, inclined at about $140^{\circ}$ angle to longitudinal axis of carapace (posterior end damaged); large, sub-rectilinear optical notch, limited by short rostrum and little-marked antero-ventral process, inclined at about $50^{\circ}$ angle to longitudinal axis of carapace; ornamentation composed of subparallel vertical rugations or terraces ("ribs"), regularly spaced from dorsal margin, and terminating in 


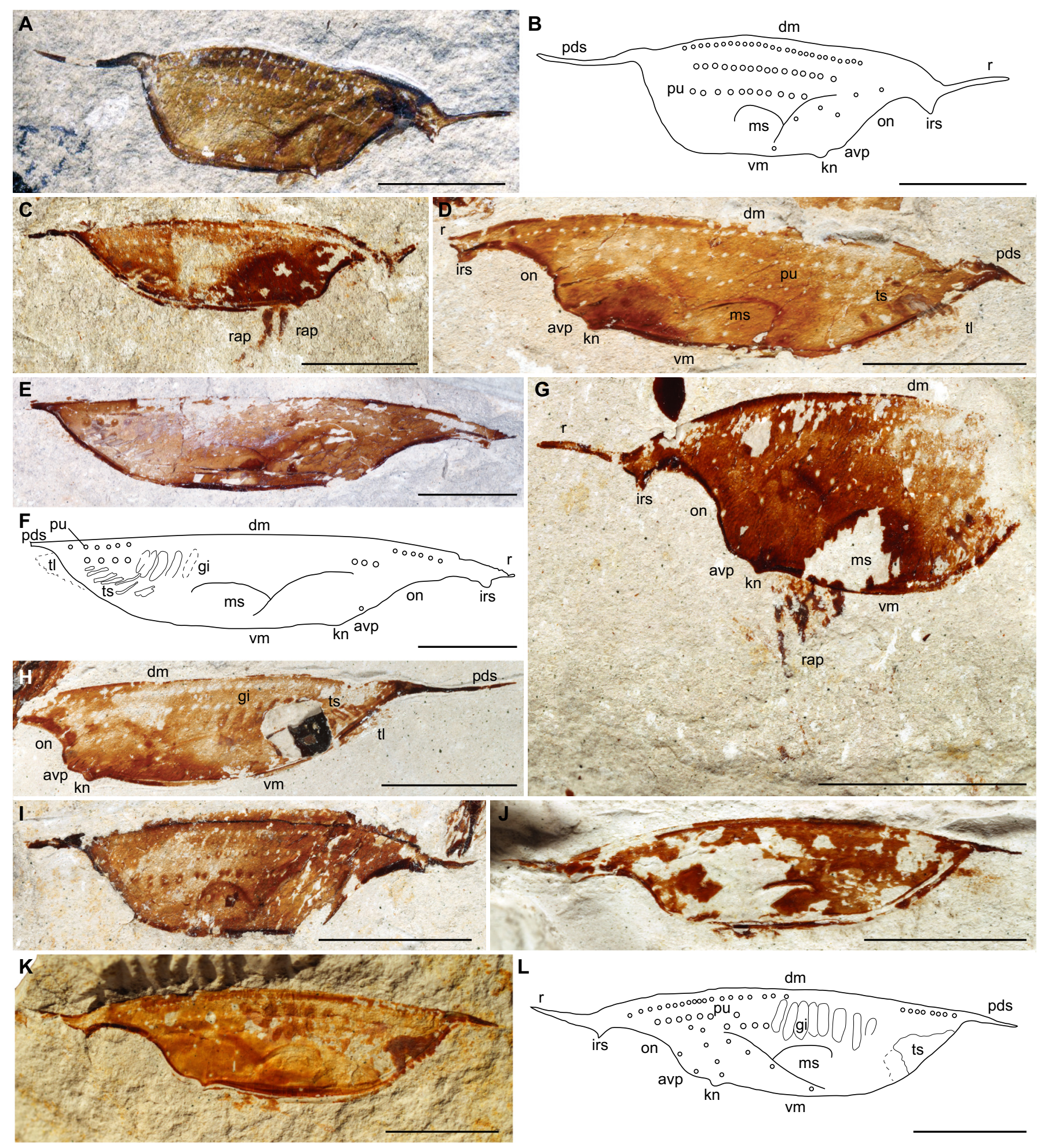

Fig. 10. Hamaticaris damesi (Roger, 1946), nov. gen., nov. comb. the Santonian of Sahel Alma, Lebanon. A-B. Paralectotype MNHN.F.B18842, carapace, right lateral view (A) and interpretative line drawing (B). C. Lectotype MNHN.F.B18843, carapace, right lateral view, note the anterior prehensile appendages. D. Paralectotype MNHN.F.A30668, carapace, left lateral view. E-F. Paralectotype MNHN.F.A30652, carapace, right lateral view (E) and interpretative line drawing (F). G. Paralectotype MNHN.F.A30655, fragment of carapace, left lateral view. H. Paralectotype MNHN.F. A30669, carapace, left lateral view. I. Paralectotype MNHN.F.A30659, carapace, right lateral view, note the Y-shaped ridges. J. Paralectotype MNHN.F. A30672, carapace, left lateral view. K-L. Paralectotype MNHN.F.A30656, carapace, left lateral view (K) and interpretative line drawing (L). Abbreviations: $\mathrm{avp}=$ antero-ventral process, $\mathrm{dm}=$ dorsal margin, gi $=$ gills, irs $=$ infra-rostral spine, $\mathrm{kn}=\mathrm{knob}, \mathrm{ms}=$ muscle scar, on $=$ optical notch, $\mathrm{pu}=$ punctuation, $\mathrm{pds}=$ postero-dorsal spine, $\mathrm{r}=$ rostrum, $\mathrm{rap}=$ prominent anterior appendages, $\mathrm{ts}=$ trunk somites, $\mathrm{tl}=$ paddle-like limbs or trunk limbs, vm = ventral margin. Scale bars: $5 \mathrm{~mm}$. Line drawing: S. Charbonnier. Photographs all in cross-polarized light: J. Haug and G. Doitteau (K). 
restricted ventral region, leaving just smooth muscle scar region; one longitudinal lateral carina in median part of carapace, superimposed to subvertical rugations; subvertical rugations presenting small deviation at level of dorsal punctuations, and stronger deviation at level of median lateral carina; points of most anterior rugations in ventral region bent backward at level of muscle scar; two rugations with bifurcate ventral extremity at level of muscle scar; no traces of limbs or soft-parts.

Taphonomy. - The almost complete carapace is damaged in the posterior region. The two halves are displaced: the dorsal region of the left half is partially visible in connection from the right one which is completely exposed. The two halves are clearly distinguishable thanks to a median dorsal line. The left half is bent and partially lying under the right one; this displacement is probably linked to a partial distortion due to a post mortem deformation.

\section{Conclusions}

The new forms herein described increase our knowledge of the thylacocephalans during the Late Cretaceous (Tab. 1, Fig. 12). The Cenomanian genera Paradollocaris, Thylacocaris, and Globulocaris are described for the first time in this work. It is surprising considering that Hadjoula and Hakel have, for a long time, been particularly renowned for their exquisite preservation of euarthropods-most notably the crustaceans (see Charbonnier et al., 2017 and references therein). The hypertrophied eyes of Paradollocaris and Thylacocaris and the probable large eyes of Globulocaris suggest relatively deep-water organisms. This was already mentioned in other Mesozoic Lagerstätten such as La Voultesur-Rhône, France (Charbonnier et al., 2010).

The thylacocephalans of Sahel Alma exhibit a remarkable diversity, known just in the Middle Jurassic of La Voulte-surRhône, France (Charbonnier, 2009). Five genera are present (Protozoea, Pseuderichthus, Thylacocephalus, Hamaticaris, Keelicaris). They are also quite abundant in terms of specimen numbers, at least concerning Protozoea hilgendorfi and Pseuderichtus cretaceus. Based on the chalky nature of the sediment from Sahel Alma and due to biases in collecting specimens in the field, no reliable statistic data are available. But, in the sampled rocks from which the bulk of the Milano collection of thylacocephalans from Sahel Alma was recovered in recent years, they appear to be the most abundant among macro-invertebrates, including far more than 1000 individuals in roughly $1 \mathrm{~m}^{3}$ of sampled rock. The diversity and abundance of the Sahel Alma thylacocephalans is surprising since they represent the last known occurrence of thylacocephalans in the fossil record.

According to Schram et al. (1999), several features of the Sahel Alma thylacocephalans suggest good swimming capacities. Indeed, the rostral and postero-dorsal and spines of Protozoea, Hamaticaris and Thylacocephalus are commonly typical of pelagic and planktic forms amongst extant crustaceans (e.g. spinose larvae or adults of dendrobranchiate shrimps and gnathophausian mysids). Such spines serve to increase buoyancy and reduce turbulent flow around the body. Moreover, the seemingly light and flexible carapaces of Protozoea and Hamaticaris is a feature found in many other thylacocephalans and swimming crustaceans. The new species
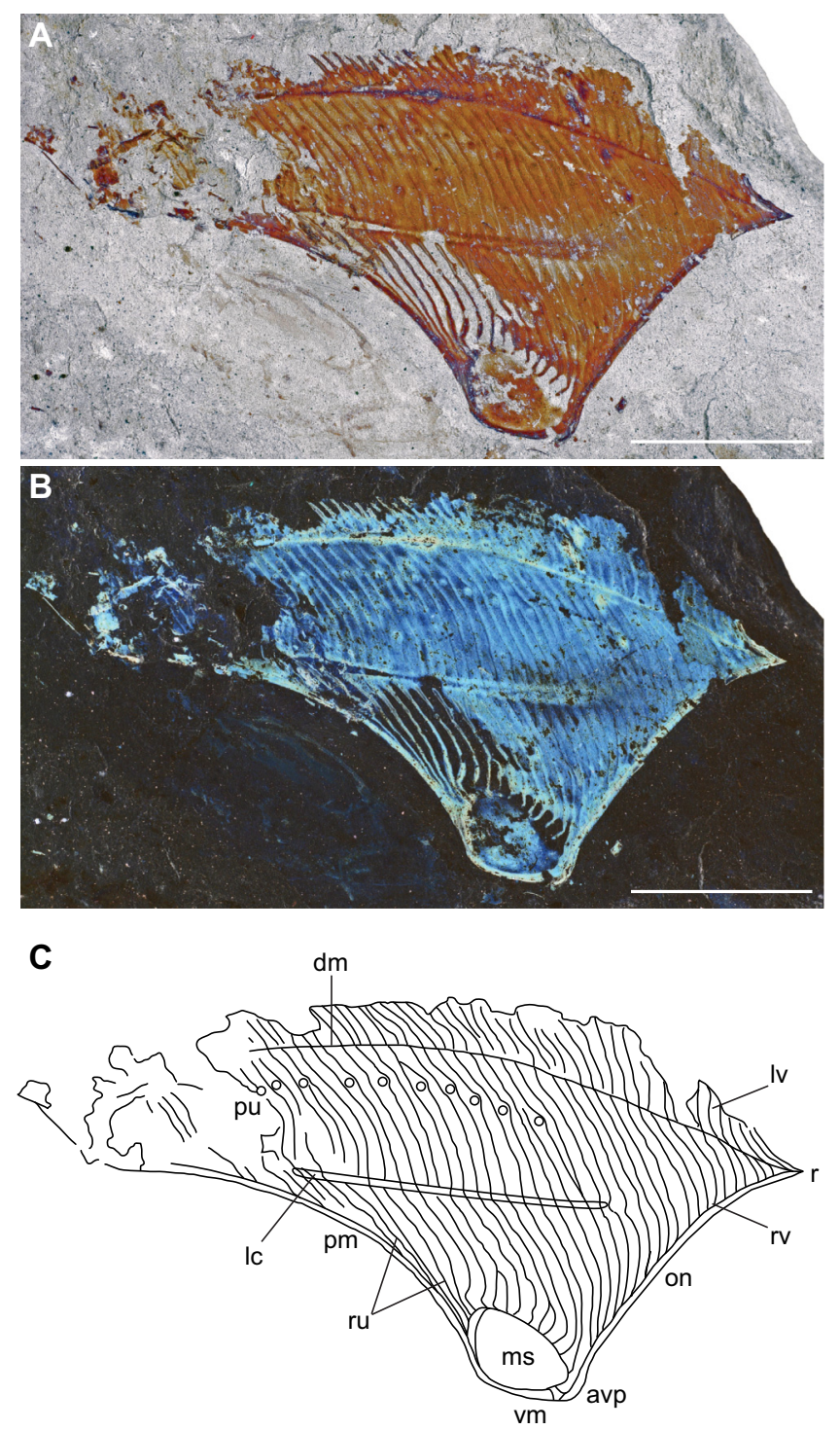

Fig. 11. Holotype MSNM i27356 of Keelicaris deborae Teruzzi and Charbonnier nov. gen, nov. sp. from the Santonian of Sahel Alma, Lebanon. A. Carapace, right lateral view, natural light. B. Carapace, right lateral view, UV light. C. Interpretative line drawing. Abbreviations: $a v p=$ antero-ventral process, $\mathrm{dm}=\mathrm{dorsal}$ margin, $\mathrm{lc}=$ lateral carina, $\mathrm{lv}=$ left valve, $\mathrm{ms}=$ muscle $\mathrm{scar}, \mathrm{on}=$ optical notch, $\mathrm{pm}=$ posterior margin, $\mathrm{pu}=$ punctuation, $\mathrm{r}=$ rostrum, $\mathrm{ru}=$ rugations or terraces, rv, right valve, vm = ventral margin. Scale bars: $1 \mathrm{~cm}$. Line drawing: S. Charbonnier. Photographs: G. Teruzzi.

of thylacocephalans from Lebanon increase the palaeobiodiversity of the last representatives of the group during the Cenomanian (Hakel, Hadjoula) and the Santonian (Sahel Alma) just before their assumed extinction. However, they do not offer any new insights into the tempo of thylacocephalan extinction at the end of the Cretaceous.

Recently, Hegna et al. (2014) reported the first known occurrences of Mesozoic thylacocephalans in the Americas in the Cretaceous Muhi Quarry Lagerstätte. These authors indicated that throughout their entire evolutionary history, 
Table 1. List of the thylacocephalans from the Konservat-Lagerstätten of Lebanon, with the number of studied specimens, the age and the distribution.

\begin{tabular}{lcc}
\hline THYLACOCEPHALA & Studied specimens & Age \\
\hline CONCHYLIOCARIDA & & Distribution \\
Dollocarididae & 17 & Cenomanian \\
Paradollocaris vannieri nov. gen., nov. sp. & 6 & Cenomanian \\
Thylacocaris schrami nov. gen., nov. sp. & & Hadjoula \\
CONCAVICARIDA & 1 & Cenomanian \\
Protozoeidae & 25 & Santonian \\
Globulocaris garassinoi nov. gen., nov. sp. & 1 & Santonian \\
Hamaticaris damesi (Roger, 1946) nov. gen., nov. comb. & 51 & Santonian \\
Keelicaris deborae nov. gen., nov. sp. & 12 & Santonian \\
Protozoea hilgendorfi Dames, 1886 & & Hakel \\
Pseuderichtus cretaceus Dames, 1886 & 3 & Sahel Alma \\
Microcarididae & Sahel Alma \\
Thylacocephalus cymolopos Lange et al., 2001 & Slma \\
\hline
\end{tabular}

A

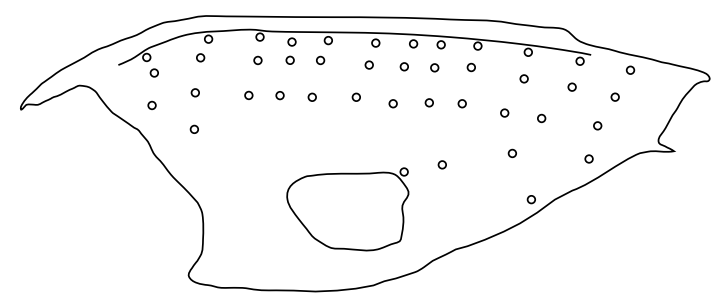

B

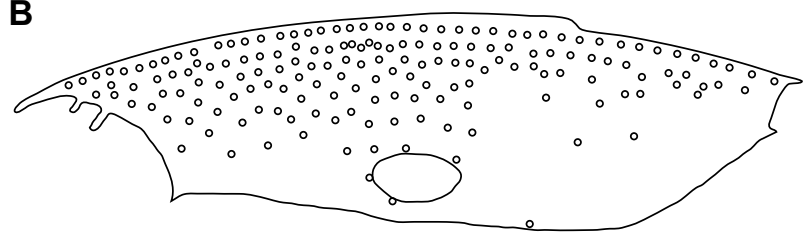

C
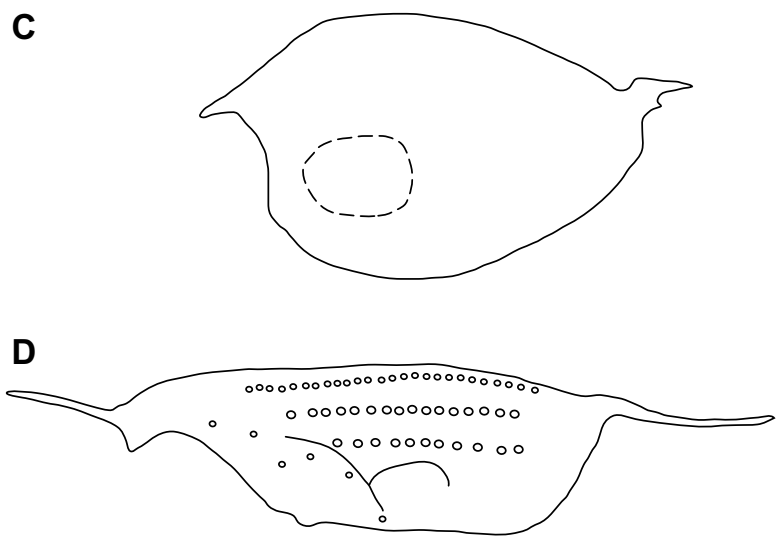

E

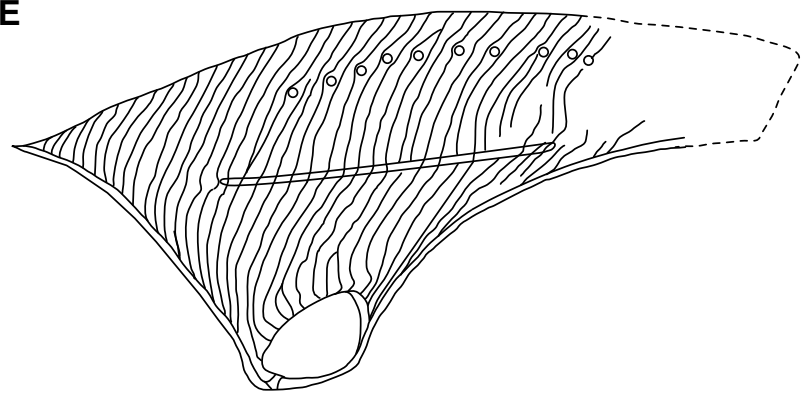

F

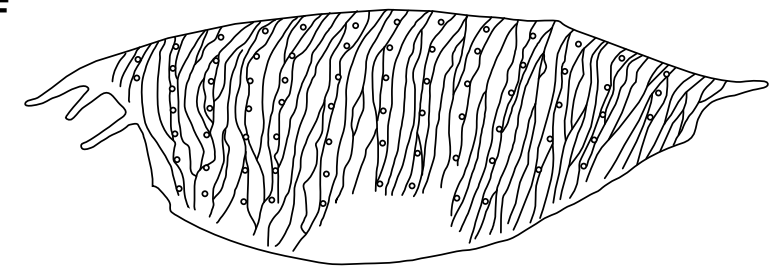

G

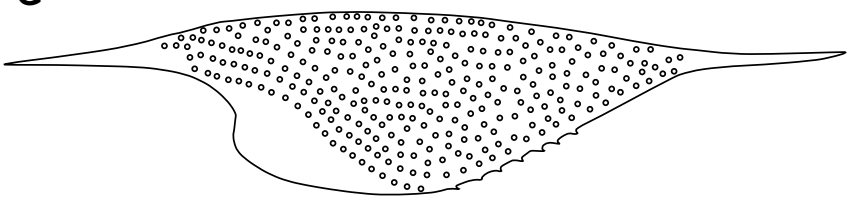

H

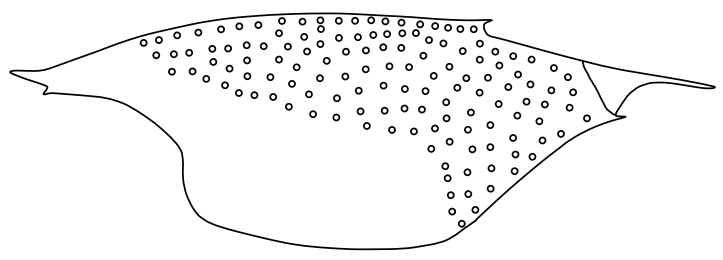

Fig. 12. Line drawings of the carapaces of the thylacocephalan genera from the Late Cretaceous Konservat-Lagerstätten of Lebanon (front part to the left). A. Paradollocaris Charbonnier nov. gen. B. Thylacocaris Audo and Charbonnier nov. gen. C. Globulocaris Teruzzi and Charbonnier nov. gen. D. Hamaticaris Charbonnier nov. gen. E. Keelicaris Teruzzi and Charbonnier nov. gen. F. Thylacocephalus Lange et al., 2001. F. Protozoea Dames, 1886. G. Pseuderichtus Dames, 1886. Line drawings: S. Charbonnier. 
thylacocephalans have a high incidence of endemism. This pattern seems to hold true until the end of the Mesozoic because, once again, there are no thylacocephalan species or genera shared between Mexico and the new species described from Lebanon. It shall be noted that the punctual fossil thylacocephalans may also explain much of this endemism.

The same authors also judiciously concluded that only more work on Lagerstätten or new localities will help us understand if the apparent range contraction of thylacocephalans at the end of the Mesozoic is a real phenomenon or an artefact of sampling. The new forms from Lebanon seem to support them: only intensive research and collect will permit to palaeontologists to find new thylacocephalans. In the present case, we sorted more than 50,000 slabs of lithographic limestone from Hakel and Hadjoula (Expedition Charbonnier 2011) to find only 25 specimens of thylacocephalans, which are herein described.

Finally, the description of these new species of thylacocephalans is another step toward a better understanding of this still enigmatic group.

Acknowledgments. We thank Frederick R. Schram and an anonymous reviewer for their valuable reviews of this work and for their useful advices. Philippe Loubry and Lilian Cazes (UMR 7207 CR2P) provided excellent photographs of specimens housed in the Paris and Milano museums. We are pleased to acknowledge Jean-Michel Pacaud (MNHN, Direction des collections) for access to the palaeontological collections. Finally, we are indebted to Pierre Abi Saad and Albert Abi Saad (Memory of Time, Byblos, Lebanon), who lead us to the outcrops in Lebanon, received us and provided us most of the specimens studied herein. The field trips of SC and DA received financial support from the Action Transversale $d u$ Muséum 2011: «Biodiversité actuelle et fossile. Crises, stress, restaurations et panchronisme : le message systématique ». The visit of JTH to the MNHN, Paris, was funded by a grant from the European Commission's (FP 6) Integrated Infrastructure Initiative programme SYNTHESYS (FR-TAF 2590).

\section{References}

Ahyong ST, Garassino A, Gironi B. 2007. Archaeosculda phoenicia n. gen., n. sp. (Crustacea, Stomatopoda, Pseudosculdidae) from the Upper Cretaceous (Cenomanian) of Lebanon. Atti della Società italiana di Scienze naturali e del Museo civico di Storia naturale in Milano 148(1): 3-15.

Arduini P, Brasca A. 1984. Atropicaris: nuovo genere della classe Thylacocephala. Atti della Società italiana di Scienze naturali e del Museo civico di Storia naturale in Milano 125(1-2): 87-93.

Arduini P, Pinna G. 1989. I Tilacocefali: una nuova classe di crostacei fossili. Milano: Museo Civico di Storia Naturale, $35 \mathrm{p}$.

Arduini P, Pinna G, Teruzzi G. 1980. A new and unusual Lower Jurassic cirriped from Osteno in Lombardy: Ostenia cypriformis n.g., n.sp. Atti della Società italiana di Scienze Naturali e del Museo Civico di Storia Naturale in Milano 121(4): 360-370.

Audo D, Charbonnier S. 2012. New Nisto of Slipper Lobster (Decapoda, Scyllaridae) from the Hadjoula Lagerstätte (Late Cretaceous, Lebanon). Journal of Crustacean Biology 32(4): 583-590.

Audo D, Charbonnier S. 2013. Late Cretaceous crest-bearing shrimps from the Sahel Alma Lagerstätte of Lebanon. Acta Palaeontologica Polonica 58(2): 335-349.
Bengtson S. 2000. Teasing fossils out of shales with cameras and computers. Palaeontologia Electronica 3(1, Art. 4): 1-14.

Bracchi G, Alessandrello A. 2005. Paleodiversity of the free-living polychaetes (Annelida, Polychaeta) and description of the new taxa from the Upper Cretaceous Lagerstätten of Haqel, Hadjoula and Al-Namoura (Lebanon). Memorie della Società italiana di Scienze naturali e del Museo civico di Storia naturale di Milano 32(3): 1-64.

Briggs DEG, Rolfe WDI. 1983. New Concavicarida (new Order: ?Crustacea) from the Upper Devonian of Gogo, Western Australia, and the palaeoecology and affinities of the group. Special Papers in Palaeontology 30: 249-276.

Brocchi P. 1875. Note sur une nouvelle espèce de crustacé fossile (Penaeus libanensis). Bulletin de la Societé géologique de France 3: 609-610.

Calzada S, Mañé R. 1993. Primera cita de un Tilacocéfalo (Crustacea) (Ferrecaris n. gen. magransi n. sp.) en el Ladiniense español. Barcelona: Trabajos Del Museo Geológico Del Seminario, vol. 246, pp. 12-16.

Charbonnier S. 2009. Le Lagerstätte de La Voulte : un environnement bathyal au Jurassique. Mémoires du Muséum national d'Histoire naturelle 199: 1-272.

Charbonnier S., Audo D, Garassino A, Hyžný M. 2017. Fossil Crustacea of Lebanon. Tome 210, 252 p.

Charbonnier S, Vannier J, Hantzpergue P, Gaillard C. 2010. Ecological significance of the arthropod fauna from the Jurassic (Callovian) La Voulte Lagerstätte. Acta Palaeontologica Polonica 55(1): 111-132.

Dames W. 1886. Ueber einige Crustaceen aus den Kreideablagerungen des Libanon. Zeitschrift der Deutschen Geologischen Gesellschaft 38: 551-575.

Ehiro M, Sasaki O, Kano H, Nemoto J, Kato H. 2015. Thylacocephala (Arthropoda) from the Lower Triassic of the South Kitakami Belt, Northeast Japan. Paleontological Research 19(4): 269-282.

Ejel F, Dubertret L. 1966. Sur l'âge précis du gisement de poissons et de crustacés crétacés de Sahel Alma (Liban). Compte rendu sommaire des séances de la Société géologique de France 9: 353-354.

Feldmann RM. 2009. A new cirolanid isopod (Crustacea) from the Cretaceous of Lebanon: dermoliths document the pre-molt condition. Journal of Crustacean Biology 29(3): 373-378.

Feldmann RM, Charbonnier S. 2011. Ibacus cottreaui Roger, 1946, reassigned to the isopod genus Cirolana (Cymothoida: Cirolanidae). Journal of Crustacean Biology 31(2): 317-319.

Ferry S, Merran Y, Grosheny D, Mroueh M. 2007. Relations entre les marges septentrionale et méridionale de la Téthys au Crétacé. Carnets de Géologie 6: 38-42.

Forey PL, Yi L, Patterson C, Davis CE. 2003 Fossil fishes from the Cenomanian (Upper Cretaceous) of Namoura, Lebanon. Journal of Systematic Palaeontology 1(4): 227-330.

Fraas O. 1878. Geologisches aus dem Libanon. Jahreshefte des Vereins für vaterländische Naturkunde in Württemberg 34: 257-391.

Gale AS. 2016. Origin and phylogeny of the Cretaceous thoracican cirripede family Stramentidae. Journal of Systematic Palaeontology 14: 653-702.

Garassino A. 1994. The macruran decapod crustaceans of the Upper Cretaceous of Lebanon. Paleontologia Lombarda 3: 3-27.

Garassino A. 2001. New decapod crustaceans in the Cenomanian (Upper Cretaceous) of Lebanon. Atti della Società italiana di Scienze naturali e del Museo civico di Storia naturale in Milano 141(2): 237-250.

Gayet M, Belouze A, Abi Saad P. 2003. Les poissons fossiles (Liban, Mémoire du temps). Méolans-Revel : Éditions DésIris, 158 p. 
Glaessner MF. 1931. Eine crustaceenfauna aus den lunzer schichten Niederösterreichs. Jahrbuch der Geologischen Bundesanstalt 81: 467-486.

Glaessner MF. 1945. Cretaceous Crustacea from Mount Lebanon, Syria. Annals and Magazine of Natural History Museum 12: 694-707.

Haug C, Haug JT, Waloszek D, Maas A, Frattigiani R, Liebau S. 2009. New methods to document fossil from lithographic limestones of southern Germany and Lebanon. Palaeontologia Electronica 12(3), 6T: 1-12.

Haug C, Van Roy P, Leipner A, Funch P, Rudkin DM, Schöllmann L, et al. 2012. A holomorph approach to xiphosuran evolution - a case study on the ontogeny of Euproops. Development Genes and Evolution 222: 253-268.

Haug C, Briggs DEG, Mikulic DG, Kluessendorf J, Haug JT. 2014. The implications of a Silurian and other thylacocephalan crustaceans for the functional morphology and systematic affinities of the group. BMC Evolutionary Biology 14: 159. DOI: 10.1186/ s12862-014-0159-2.

Haug JT, Haug C. 2011. Fossilien unter langwelligem Licht: GrünOrange-Fluoreszenz an makroskopischen Objeckten. Archaeopteryx 29: 20-23.

Haug JT, Audo D., Charbonnier S, Palero F, Petit G, Abi Saad P, et al. 2016. The evolution of a key character, or how to evolve a slipper lobster. Arthropod Structure \& Development 45: 97-107.

Haug JT, Haug C, Kutschera V, Mayer G, Maas A, Liebau S, et al. 2011. Autofluorescence imaging, an excellent tool for comparative morphology. Journal of Microscopy 244: 259-272.

Hegna TA, Vega FJ, González-Rodríguez KA. 2014. First Mesozoic thylacocephalans (Arthropoda, ?Crustacea; Cretaceous) in the Western Hemisphere, new discoveries from the Muhi Quarry Lagerstätte. Journal of Paleontology 88(3): 606-616.

Hemleben C von. 1977. Rote Tiden und die oberkretazischen Plattenkalke im Libanon. Neues Jahrbuch für Geologie und Paläontologie, Monatshefte 1977(4): 239-255.

Hilgendorf F. 1885. Ueber cretacische Squilliden-Larven vom Libanon. Sitzungs-Berichte der Gesellschaft naturforschender Freunde zu Berlin 1885(10): 184-185.

ICZN 1999. International Code of Zoological Nomenclature. International Trust for Zoological Nomenclature. The Natural Museum, London, v-xxix +306 p.

Jattiot R, Brayard A, Fara E, Charbonnier S. 2015. Gladius-bearing coleoids from the Upper Cretaceous Lebanese Lagerstätten: diversity, morphology and phylogenetic implications. Journal of Paleontology 89(1): 148-167.

Lange S, Hof CHJ, Schram FR, Steeman FA. 2001. New genus and species from the Cretaceous of Lebanon links the Thylacocephala to the Crustacea. Palaeontology 44(5): 905-912.

Pinna G. 1974. I crostacei della fauna triassica di Cene in Val Seriana. Memorie della Società italiana di Scienze naturali e del Museo civico di Storia naturale di Milano 21(1): 5-34.
Pinna G, Arduini P, Pesarini C, Teruzzi G. 1982. Thylacocephala: una nuova classe di crostacei fossili. Atti della Società Italiana di Scienze Naturali e del Museo Civico di Storia Naturale in Milano 123: 469-482.

Polz H. 1994. Mayrocaris bucculata gen. nov. sp. nov. (Thylacocephala, Conchyliocarida) aus den Solnhofener Plattenkalken. Archaeopteryx 12: 35-44.

Roger J. 1946. Invertébrés des couches à poissons du Crétacé supérieur du Liban. Mémoires de la Société géologique de France (Nouvelle série) 51: 5-92.

Rolfe WDI. 1985. Form and function in Thylacocephala, Conchyliocarida and Concavicarida (?Crustacea): a problem of interpretation. Transactions of the Royal Society of Edinburgh 76: 391-399.

Schram FR. 1990. On Mazon Creek Thylacocephala. Proceedings of the San Diego Society of Natural History 3: 1-16.

Schram FR. 2014. Family level classification within Thylacocephala, with comments on their evolution and possible relationships. Crustaceana 87(3): 340-363.

Schram FR, Hof CHJ, Steeman FA. 1999. Thylacocephala (Arthropoda: Crustacea?) from the Cretaceous of Lebanon and implications for thylacocephalan systematics. Palaeontology 42(5): 769-797.

Secrétan S. 1983. Une nouvelle classe fossile dans la super-classe des Crustacés: Conchyliocarida. Comptes Rendus de l'Académie des Sciences, Paris 296(2): 741-743.

Secrétan S. 1985. Conchyliocarida, a class of fossil crustaceans: relationship to Malacostraca and postulated behaviour. Transactions of the Royal Society of Edinburgh 76: 381-389.

Tintori A, Bigi E, Crugnola G, Danini G. 1986. A new Jurassic Thylacocephala Rugocaris indunensis gen. n. sp. n. and its paleoecological significance. Rivista Italiana di Paleontologia e Stratigrafia 92(2): 239-250.

Vannier J, Chen J-Y, Huang D-Y, Charbonnier S, Wang X-Q. 2006. The Early Cambrian origin of thylacocephalan arthropods. Acta Palaeontologica Polonica 51(2): 201-214.

Vannier J, Schoenemann B, Gillot T, Charbonnier S, Clarkson E. 2016. Exceptional preservation of eye structure in arthropod visual predators from the Middle Jurassic. Nature Communications 7, 10320. DOI: $10.1038 /$ ncomms 10320.

Van Straelen V. 1923. Les Mysidacés du Callovien de La Voultesur-Rhône (Ardèche). Bulletin de la Société géologique de France Earth Sciences Bulletin 23(4): 431-439.

Van Straelen V. 1938. Sur une forme larvaire nouvelle de stomatopodes du Cénomanien du Liban. Palaeobiologica 6(2): 394-400.

Wippich G, Lehmann J. 2004. Allocrioceras from the Cenomanian (mid-Cretaceous) of the Lebanon and its bearing on the palaeobiological interpretation of heteromorphic ammonites. Palaeontology 47(5): 1093-1109.

Cite this article as: Charbonnier S, Teruzzi G, Audo D, Lasseron M, Haug C, Haug JT. 2017. New thylacocephalans from the Cretaceous Lagerstätten of Lebanon, Bull. Soc. géol. Fr. 188: 19. 